\title{
Genetic and Environmental Factors in Complex Neurodevelopmental Disorders
}

\author{
K.M.J. van Loo and G.J.M. Martens*
}

\begin{abstract}
Department of Molecular Animal Physiology, Donders Institute for Neuroscience, Nijmegen Center for Molecular Life Sciences (NCMLS), Faculty of Science, Radboud University Nijmegen, Geert Grooteplein Zuid 28, 6525 GA Nijmegen, The Netherlands
\end{abstract}

\begin{abstract}
Complex neurodevelopmental disorders, such as schizophrenia, autism, attention deficit (hyperactivity) disorder, (manic) depressive illness and addiction, are thought to result from an interaction between genetic and environmental factors. Association studies on candidate genes and genome-wide linkage analyses have identified many susceptibility chromosomal regions and genes, but considerable efforts to replicate association have been surprisingly often disappointing. Here, we summarize the current knowledge of the genetic contribution to complex neurodevelopmental disorders, focusing on the findings from association and linkage studies. Furthermore, the contribution of the interaction of the genetic with environmental and epigenetic factors to the aetiology of complex neurodevelopmental disorders as well as suggestions for future research are discussed.
\end{abstract}

Received on: October 25, 2007 - Revised on: November 7, 2007 - Accepted on: November 9, 2007

Key Words: Neurodevelopmental disorders, susceptibility genes, environmental factors, gene-environment interactions, association studies, linkage analysis.

\section{INTRODUCTION}

The term neurodevelopmental disorder is a relatively new term and includes a group of disorders with severely affected behavioral features caused by alterations in early brain development. Most neurodevelopmental disorders are associated with a life-long endurance and have a severe impact on normal brain functioning, leading to affected behavior often resulting in large economical, emotional and physical problems, not only for the individual but also for the family and society as a whole. The various neurodevelopmental disorders show similar features, including brain dysfunctioning (such as difficulties in sensor and motor systems, problems with speech and language) and a number of cognitive impairments (e.g. in learning and organizational skills). Schizophrenia, autistic disorders, attention deficit hyperactivity disorder (ADHD), bipolar disorder, mental retardation and Tourette's syndrome are some of the more common neurodevelopmental disorders, but also Rett syndrome, immunodeficiency, centromeric region instability, facial anomalies (ICF) syndrome and X-linked alpha thalassemia/mental retardation (ATR-X) syndrome are considered neurodevelopmental disorders (Table 1).

\section{NEURODEVELOPMENTAL DISORDERS AND GE- NETIC AETIOLOGY}

Neurodevelopmental disorders can be divided into four subgroups, based on their (mostly hypothetical) genetic aetio-

\footnotetext{
*Address correspondence to this author at the Department of Molecular Animal Physiology, Donders Institute for Neuroscience and Nijmegen Center for Molecular Life Sciences (NCMLS), Radboud University Nijmegen, 193 RT, Geert Grooteplein Zuid 28, 6525 GA Nijmegen, The Netherlands; Tel: 31-24-3610564; Fax: 31-24-3615317; E-mail: g.martens@ncmls.ru.nl
}

logy (Table 1). The first subgroup is characterized by aneuploidy (an abnormal number of chromosomes). The most well-known neurodevelopmental aneuploidy is Down's syndrome with a trisomy of chromosome 21. Disorders of the second subgroup contain chromosomal micro-deletions, such as the deletion of chromosomal region $7 \mathrm{q} 11.2$ (which harbours more than 20 genes) in William's-Beuren syndrome. In each neurodevelopmental disorder of the third subgroup, only a single gene is affected. For example, the fragile $\mathrm{X}$ syndrome is a genetic disorder caused by a mutation (CGG repeat expansion) of the fragile $\mathrm{X}$ mental retardation 1 (FMR1) gene on the $\mathrm{X}$ chromosome. The neurodevelopmental disorders with a complex aetiology, such as autism and schizophrenia, comprise the fourth subgroup and are thought to be caused by (a combination of) genetic, environmental and epigenetic factors. In this review, we focus on the neurodevelopmental disorders with a complex aetiology and the current thoughts on their genetic, environmental and epigenetic aetiologies.

\section{IDENTIFICATION OF SUSCEPTIBILITY LOCI AND GENES}

Twin, family and adoption studies have revealed an unambiguous role for genetic factors in the aetiology of complex neurodevelopmental disorders that can even exceed an estimated heritability of $90 \%$ (in autism; Table 2). Although a genetic component is thus clearly involved in the aetiology of a complex neurodevelopmental disorder, it is still elusive which gene (or genes) is responsible for its pathogenesis. Historically, the dopamine and also the glutamate neurotransmission system have often been implicated to play a role in neurodevelopmental pathogenesis. However, since many recently identified susceptibility genes have been found not to be related to either of the two neurotransmitter 
Table 1. Neurodevelopmental Disorders and their Genetic Aetiologies

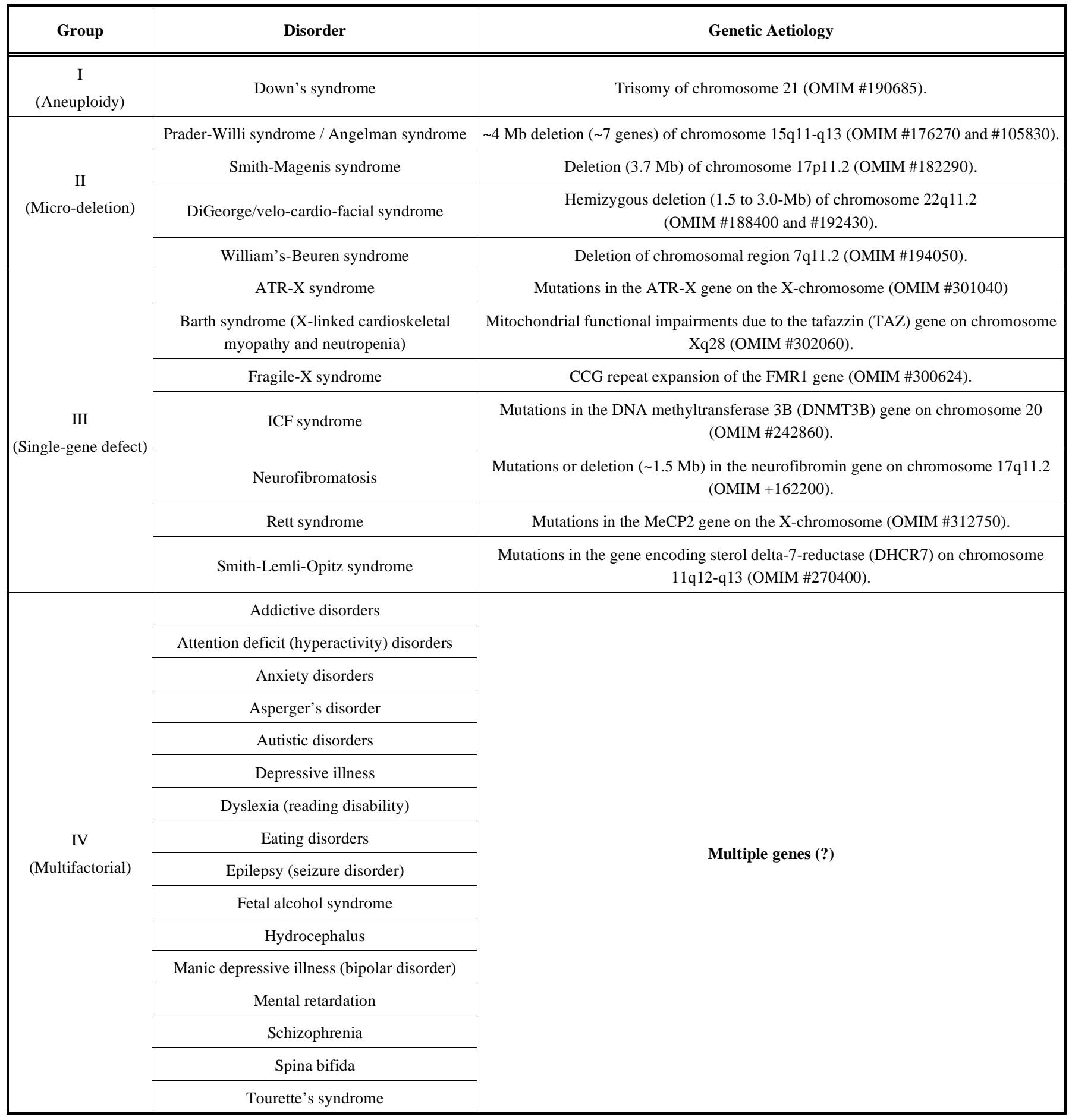

systems, restriction to these systems is no longer justified. To identify susceptibility genes and to better understand the pathophysiology of complex neurodevelopmental disorders, many studies utilizing genetic, biochemical, pharmacological, neurological and cognitive neuroscience techniques have been performed. In this section, we summarize the genetic approaches that have been used to identify risk factors at specific loci and genes.

\section{Linkage Studies}

Linkage analysis is a method to locate disease-related loci using DNA markers across the genome that travel with a disease within families. The main advantage of linkage analysis is that it involves family-based analysis, and thus eliminates the problem of ethnical stratification. However, linkage analysis has a relatively low power to detect smalleffect variations [1]. 
Table 2. Estimated Heritability of Complex Neurodevelopmental Disorders

\begin{tabular}{|c|c|c|}
\hline Disorder & Estimated Heritability & References \\
\hline \hline Autism & $>90 \%$ & {$[9]$} \\
\hline Schizophrenia & $80 \%$ & {$[17]$} \\
\hline ADHD & $70 \%$ & {$[36]$} \\
\hline Epilepsy & $70 \%$ & {$[60]$} \\
\hline Drug addiction & $70 \%$ & {$[91]$} \\
\hline Spina bifida & $70 \%$ & {$[212]$} \\
\hline Bipolar disorder & $63 \%$ & {$[22]$} \\
\hline Eating disorders & $48-74 \%$ & {$[154,156]$} \\
\hline Dyslexia & $50-70 \%$ & {$[213]$} \\
\hline Alcohol addiction & $50-60 \%$ & {$[90]$} \\
\hline Panic disorder & $30-46 \%$ & {$[214]$} \\
\hline Posttraumatic stress disorder & $30 \%$ & {$[148]$} \\
\hline Obsessive-compulsive disorder & $26-47 \%$ & {$[215,216]$} \\
\hline Anxiety disorders & $30-40 \%$ & {$[108]$} \\
\hline Depressive illness & $37 \%$ & {$[27]$} \\
\hline
\end{tabular}

\section{Association Studies}

Numerous association studies have been performed to test for association between genetic variations and neurodevelopmental disorders [2,3]. Compared to linkage analysis, one important advantage of association studies concerns its improved power when equal cohort sizes are used [4]. In association studies, the genotype or allele frequencies of genetic variations between patients and controls (non-related individuals; case-control design) or between parents and their offspring (related individuals; family-based design) is compared. For the case-control design, a more than by chance predicted difference in the frequency of a singlenucleotide polymorphism (SNP) between the cases and controls indicates that the specific polymorphism may increase or decrease risk for the disorder, or is in linkage disequilibrium with a nearby genetic variant. The frequencies of genetic varations may vary among individuals from a different geographical or ethnical background and therefore a well-defined cohort is necessary. For family-based association studies, the parents function as the controls for the affected offspring (so-called trio-study). If the SNP is transmitted from the parents to the offspring as expected by chance alone, no association with the disorder is present. Transmission of the SNP at a higher degree than expected by chance suggests association of the genetic marker with the affected phenotype.

Having decided on the study design and study samples, the next step is to select appropriate candidate genes. In general, a gene is selected with some a priori relationship with the disorder, based on its localization (i.e. the gene is located in a chromosomal region with a significant linkage), or proposed function in the pathogenesis of the disorder (e.g. the gene belongs to the dopamine or serotonin pathway in association studies for schizophrenia pathogenesis). Genomewide association (GWA) studies can now also be performed, whereby large numbers of DNA polymorphisms are analyzed in one experiment.

\section{Copy Number Variations}

Recently, it became clear that besides mutations and SNPs (both coding and non-coding alterations) also genomic rearrangements and gene-dosage imbalances (duplications, deletions and inversions) play a role in the pathogenesis of a number of nervous system disorders [reviewed in 5]. These structural variants are common and ubiquitous in the genome and can range from kilobases to megabases in size. The human genome contains at least 1447 copy-number variants (CNVs), covering 360 megabases and comprising $12 \%$ of the genome [6]. Previous knowledge of CNVs in relation to diseases was limited due to insufficient methods to detect CNVs. Only large CNVs detected with cytogenetic techniques, such as G-banding (Giemsa staining) and fluorescence in situ hybridization, have been previously identified. The advent of high-resolution genome-wide methods has significantly improved the power to detect CNVs.

At present, one of the most attractive techniques to detect CNVs is comparative genome hybridization (CGH) using DNA microarrays containing genomic DNA probes (e.g. bacterial artificial chromosome clones, cDNA clones or oligonucleotides). The $\mathrm{CGH}$ technology allows a genome-wide screening with a relatively high resolution (with the resolution depending on the number, distribution and lengths of the probes present on the array), and may be particularly useful for the identification of CNVs that are too small to detect via routine cytogenetic analyses. Another type of array that can be used for detecting CNVs is the genome-wide SNP array. Besides normal SNP analysis (i.e. the identification of a single-base polymorphism), these arrays also give intensity information and thereby the corresponding copy number of a genomic region. Once CNVs have been detected, studies for locus-specific $\mathrm{CNV}$ association have to be designed, such as targeted quantitative and semiquantitative PCR, multiplex ligation-dependent probe amplification or dynamic allelespecific hybridization.

\section{mRNA and Protein Expression Profiling}

The principle of mRNA and protein profiling is to identify genes that are differentially expressed in selected tissues of cases and (matched) controls. One of the promising strategies is the use of human post-mortem brain tissues, from which nowadays good quality mRNA can be extracted for microarray analysis [7]. However, when performing such studies one has to be aware of the possibility that the differential expression could be caused by years of medicine usage or by pre- or post-mortem artifacts.

\section{Animal Models}

The use of animal models for the analysis of complex neurodevelopmental disorders appears to be an attractive alternative to circumvent the problems encountered when 
human material is used for mRNA or protein profiling. However, animals do not exhibit higher-order functions, some of which may be associated with complex human disorders. Nevertheless, one can take advantage of specific characteristics (endophenotypes) of an animal model to study the genetic and environmental factors that lead to a particular phenotypic outcome.

Several categories of animal models may be employed, including models based on a behavioral selection (e.g. the endophenotype prepulse inhibition), on a pharmacological selection (e.g. the psychotic effects of drugs, such as amphetamine) or on brain lesions (e.g. animal models with disconnections of the hippocampus). In addition, genetic animal models - with targeted genetic manipulations of specific genes - can be used, including knockout and transgenic models. Genetically modified animals can be subjected to a whole battery of behavioral tests to understand the role of a gene in neurodevelopmental aetiology. Furthermore, such models can be used to study environmental manipulations, including maternal or chronic stress paradigms.

\section{SUSCEPTIBILITY LOCI AND GENES OF COMPLEX NEURODEVELOPMENTAL DISORDERS}

In the past decades, an impressive amount of linkage and association studies have been performed. However, conclusive evidence from the numerous genetic linkage and association studies has not yet been obtained. The studies have continuously led to inconsistent and controversial findings. In the next paragraphs, the genetic aetiology of the complex neurodevelopmental disorders is summarized. However, because positive associations are often published more easily one has to realize publication bias and the fact that even results obtained by meta-analysis may represent false positives.

\section{Autism}

Autism has a prevalence of $\sim 0.6 \%$ in the general population and is four times more prevalent in boys than in girls. Together with four other disorders (Asperger's disorder, childhood disintegrative disorder, Rett syndrome and Personality Disorder Not Otherwise Specified) it belongs to the group of Pervasive Developmental Disorders (PDD). Autism is the most common PDD and usually appears during the first three years of life. Its symptoms include impairments in verbal and nonverbal communication, lack of social interaction, and restricted and stereotypical behaviour [8]. Though autism is one of the most hereditary disorders in psychiatry, with an estimated heritability of up to $90 \%$ (Table 2) [9], the search for susceptibility genes has proven to be complex. Until now, a number of chromosomal loci have been identified that may represent regions predisposing to autism, including regions on chromosome 1p12-p21.1, 1q21-q44, 2q24.1-q33.1, 3q21.3-q29, 4q21.3-q35.1, 5p12-p15.33, 6q14.3-q23.2, 7q21.2-q36.2, 10p12.1-p14, 10q23.3-q26.3, 13q12.13-q33.1, 15q13.1-q26.1, 16p12.1-p13.3, 17q11.1q21.2, 19p13.11-p13.3 and 19q12-q13.12 [reviewed in 10]. Although most susceptibility regions have been studied in more detail via the candidate-gene approach (e.g. the Reelin gene on chromosome $7 \mathrm{q} 22$ and the serotonin transporter gene (SLC6A4) on chromosome 17q11.1-q12), no gene has been found to clearly contribute to autism susceptibility. Recently, the first GWA studies for autism have been reported with significant associations, including CNVs, found in several genetic loci [11-13], but the results have been inconclusive. Thus, despite the high heritability estimates for autism, its genetic aetiology still needs to be elucidated.

\section{Schizophrenia}

Schizophrenia is a common mental disorder affecting approximately $1 \%$ of the population [14]. It generally emerges between 16 and 30 years of age and is characterized by three main symptoms: cognitive disturbances, psychosis and negative symptoms [15]. Unfortunately, there are no genetic markers available for diagnosing schizophrenia. Therefore, diagnosis can only be based on clinical symptoms using the Diagnostic and Statistical manual for mental disorders version IV (DSM-IV, 2000) or the International Classification of Disease version 10 (ICD-10, 1992).

The first genetic studies on schizophrenia date back from 1916 and addressed the question whether the disorder has a genetic aetiology. Many subsequent family, twin and adoption studies clearly revealed the importance of a genetic component in schizophrenia [16] with an estimated heritability of around $80 \%$ (Table 2) [17], but the responsible gene (or genes) is still elusive. Although many susceptibility loci have been identified, numerous inconsistent and controversial findings have been reported. The genes most often reported to be related to schizophrenia are the genes encoding disrupted in schizophrenia 1 (DISC1; 1q42.1), neuregulin-1 (NRG1; 8p12), dysbindin (DTNBP1; 6p22.3), D-amino acid oxidase activator (DAOA or G72;13q34), D-amino-acid oxidase (DAO; 12q24), regulator of G-protein signaling 4 (RGS4; 1q23.3) and the dopamine-catabolizing enzyme catechol-O-methyl transferase (COMT; 22q11.21) [reviewed in 18,19$]$. However, relative risk effects of the variations range between 1.5 to 2.0 , indicating only small-effect sizes. Recently, the first GWA study for schizophrenia using the Affymetrix GeneChip 500K Mapping Array Set on 178 schizophrenic patients and 144 controls has been reported. One SNP (rs4129148) close to the colony stimulating factor 2 receptor alpha chain gene (CSF2RA) on chromosome $\mathrm{Xp} 22.32$ and Yp11.3 showed association beyond the genome-wide significance threshold [20]. Independent replications to confirm this finding are however necessary. (For a more detailed overview of the genes reported to be associated with schizophrenia, we refer to http://www.polygenicpathways.co.uk/schizgenesandfunc.html).

\section{Bipolar Disorder}

Bipolar disorder, also known as manic-depressive illness, is a severe mental disorder characterized by recurrent manic and depressive episodes causing dramatic mood swings. The prevalence of bipolar disorder is estimated to be $0.8-2.6 \%$ [21]. Although some have their first symptoms in childhood, most patients develop episodes in late adolescence or early adulthood. Bipolar disorder patients show many clinical features that are similar to those of schizophrenic patients, such as age of onset, psychotic symptoms, episodic courses of illness and a lifelong endurance. However, also clear distinctions exist between the two disorders. For example, bipolar 
disorder manifests as an impairment of mood, whereas schizophrenia is a primary disorder of cognition. Furthermore, most bipolar patients benefit from lithium therapy, whereas schizophrenics seldom do.

Twin and family studies have shown that bipolar disorder tends to run in families with an estimated genetic hereditary of $63 \%$ [22]. Interestingly, besides the shared clinical symptoms, bipolar disorder and schizophrenia may also share a genetic background [23]. A number of promising susceptibility genes for schizophrenia have been reported to associate with bipolar disorder as well, including G72, DAO, DISC1, NRG1, RGS4, COMT, neural cell adhesion molecule 1 (NCAM1; 11q23.1), brain-derived neurotrophic factor (BDNF; 11p13) glutamate receptor, metabotropic 3 and 4 (GRM3; 7q21.1-q21.2 and GRM4; 6p21.3), glutamate receptor, ionotropic, N-methyl D-aspartate 2B (GRIN2B; 12p12), megalencephalic leukoencephalopathy with subcortical cysts 1 (MLC1; 22q13.33), synaptogyrin 1 (SYNGR1; 22q13.1) and solute carrier family 12 (potassium/chloride transporters), member 6 (SLC12A6; 15q13-q15) [reviewed in 21, 24]. Recently, The Wellcome Trust Case Control Consortium reported a GWA study on bipolar disorder using the Affymetrix GeneChip 500K Mapping Array Set and found one chromosomal region with strong evidence of association (16p12) and 13 regions with moderate association (2p25, $2 q 12,2 q 14,2 q 37,3 p 23,3 q 27,6 p 21,8 p 12,9 q 32,14 q 22$, 14q32, 16q12 and 20p13) [25]. (For a complete list of the genetic associations with bipolar disorder, we refer to http://www.polygenicpathways.co.uk/Bipolargenes.html).

\section{Major Depression}

Like bipolar disorder, depression is a major mood disorder. Although many clinical aspects are comparable between major depression and bipolar disorder, a number of characteristics are different between the two disorders: depression is much more heterogeneous, has a higher environmental contribution and has a higher prevalence with an overall lifetime risk of $16.2 \%$ in the United States [26]. Since the genetic contribution to major depression is only $37 \%$ [27] and the illness is highly heterogeneous, unravelling its genetic pathogenesis is extremely difficult. To date, no clear genetic risk factors for major depression have been identified. Most studies have focused on well-known polymorphisms that have been hypothesized to associate with other psychiatric disorders. For example, the Val66Met variant in the BDNF gene, the short allele of the SLC6A4 gene, and the Val158Met variation in the COMT gene have been studied in depression cohorts [28-30], but the results are contradictory [31-33].

\section{ADHD}

ADHD was first described in 1845 and affects up to 1 in 20 children $[34,35]$. The principal problem for children with ADHD is the impairment to control their behaviour, due to inattention, hyperactivity and impulsivity. According to the DSM-IV guidelines, these symptoms should appear early in a child's life, before age 7, and should continue for at least 6 months, otherwise the diagnosis ADHD is not justified. Other disorders often accompany ADHD, including learning disabilities, oppositional defiant disorder, conduct disorder, Tourette's syndrome and/or depressive illness.
Twin studies have indicated a relatively high genetic contribution reaching an average of 70\% [36]. Thus far, many candidate gene studies on ADHD have focused on the dopamine and serotonin pathways. Meta-analyses of the available data have suggested several of the genes belonging to either pathway to be involved in ADHD pathogenesis, including the dopamine receptors D4 (DRD4; 11p15.5) and D5 (DRD5; 4p16.1), SLC6A4, the dopamine transporter (DAT or SLC6A3; 5p15.3), the 5-hydroxytryptamine (serotonin) receptor 1B (HTR1B; 6q13), dopamine beta-hydroxylase (DBH; 9q34) and synaptosomal-associated protein of $25 \mathrm{kDa}$ (SNAP25; 20p12-p11.2) [reviewed in 36]. In addition, recently a large candidate gene analysis was performed involving 1,038 SNPs and spanning 51 candidate genes (belonging to the circadian rhythm genes and the dopamine, norepinephrine or serotonin pathways) that confirmed association with DRD4 and DAT1 [37], the two most replicated associations.

\section{Tourette's Syndrome}

Tourette's syndrome (also called Gilles de la Tourette syndrome) is a neuropsychiatric disorder that occurs with an estimated prevalence of $1 \%$ among school-age children [38], is characterized by multiple chronic tics (involuntary movements and vocalizations) and is often accompanied by other behavioural disorders, including ADHD and obsessivecompulsive disorder (OCD) [34]. Although family and twin studies have suggested a contribution of genetic factors in Tourette's syndrome, its precise contribution rate remains unclear [39]. Until now, most association studies have focussed on candidate genes belonging to the dopaminergic pathway, and showed several positive associations for the DAT, monoamine oxidase A (MAOA; Xp11.3) and the dopamine receptors D2 (DRD2; 11q23), D3 (DRD3; 3q13.3) and D4 [40-47]. However, since not all subsequent replication studies were positive [48-53] and other genes were found to associate as well [54], the contribution of the dopaminergic pathway to Tourette's syndrome remains to be established.

\section{Dyslexia (Reading Disability)}

Dyslexia affects 5-10\% of school-age children [55] and is characterized by problems with word recognition and spelling. Linkage studies have revealed a number of chromosomal susceptibility loci for dyslexia (1p34-p36, 2p16-p15, 3p12-q12, 6p21, 6q13-q16, 11p15, 15q21, 18p11 and Xq27) [reviewed in 56]. Within and near these loci several genes have been studied using association analyses, resulting in a few candidate genes for dyslexia: dyslexia susceptibility 1 candidate 1 (DYX1C1; 15q21) [57], roundabout Drosophila homolog 1 (ROBO1; 3p12) [58] and doublecortin domaincontaining protein 2 (DCDC2; 6p22.1) [59], but again the results are not conclusive and therefore the genetic aetiology of dyslexia is currently still unclear.

\section{Epilepsy (Seizure Disorder)}

Epilepsy is a heterogeneous group of disorders with abnormal electrical brain activity. In adults, temporal lobe epilepsy (TLE) is the most common form of epilepsy with an age of onset in late childhood or adolescence. In childhood, the most common form of epilepsy is febrile seizures (FSs), 
with a prevalence of $2-5 \%$ in Western countries and an estimated heritability of $70 \%$ [60]. Genetic linkage analyses have identified a number of loci for familial FS, including the loci on chromosome 19p13.3, 2q23-q24, 5q14-q15 and 18 p11.2 containing the genes encoding casein kinase I gamma 2 isoform (CSNK1G2; 19p13.3), sodium channel, voltage-gated, type I, alpha subunit (SCN1A; 2q24.3), G protein-coupled receptor 98 (GPR98; 5q13) and inositol(myo)-1(or 4)-monophosphatase 2 (IMPA2; 18p11.2), respectively [61-64]. Although linkage of these loci has been replicated in some other familial cases, only for CSNK1G2 and IMPA2 association was found in subsequent association analysis [64, 65]. In addition, a number of other candidate genes have been identified via association studies, including the genes encoding cholinergic receptor nicotinic alpha 4 (CHRNA4; 20q13.2-q13.3), gamma-aminobutyric acid A receptor gamma 2 (GABRG2; 5q31.1-q33.1) and -beta 3 (GABRB3; 15q11.2-q12), interleukin 1 beta (IL1B; 2q14) and interleukin 1 receptor antagonist (IL1RN; 2q14.2) [6670]. However, the latter associations could not be replicated in subsequent cohorts [71-75].

\section{Mental Retardation}

Mental retardation (MR) occurs in approximately 2-3\% of the population in developed countries [76]. For the diagnosis MR a number of criteria have to be fulfilled, including an IQ lower than 70 and behavioural disabilities that are already evident in childhood. The underlying causes of MR can be diverse, varying from inborn causes such as Down's syndrome, Fragile $\mathrm{X}$ syndrome and fetal alcohol syndrome (these three causes are responsible for 30\% of the MR cases [77]), but also malnutrition and problems during pregnancy or birth can increase the risk for MR [78].

Although it is evident that a genetic factor is involved in the aetiology of MR and the genetic cause of a number of subtypes has been identified (e.g. trisomy of chromosome 21 in Down's syndrome), the majority of cases have an unknown genetic aetiology. Since MR has a clearly X-linked inheritance pattern and is more often found in males than females, variations in the X-chromosome may increase the risk for MR. A number of X-linked genes have been identified as susceptibility genes for MR, including fragile $\mathrm{X}$ mental retardation 2 (FMR2; Xq28), oligophrenin 1 (OPHN1; Xq12), p21 (CDKN1A)-activated kinase 3 (PAK3; Xq22.323), GDP dissociation inhibitor 1 (GDI1; Xq28), Rac/Cdc42 guanine nucleotide exchange factor (GEF) 6 (ARHGEF6; Xq26), ribosomal protein S6 kinase, 90kDa, polypeptide 3 (RPS6KA3; Xp22.2-p22.1), interleukin 1 receptor accessory protein-like 1 (IL1RAPL1; Xp22.1-p21.3), tetraspanin 7 (TSPAN7; Xp11.4), methyl CpG binding protein 2 (MECP2; Xq28), acyl-CoA synthetase long-chain family member 4 (ACSL4; Xq22.3-q23) and aristaless related homeobox (ARX; Xp21) [79-89]. However, many other genes are likely linked to MR.

\section{Addictive Disorders}

Many twin studies have been performed on addictive disorders (both alcohol and drug abuse), which indicated heritability levels of $50-60 \%$ in alcohol consumption [90] and up to $70 \%$ in severe smoking [91]. Since the dopaminer- gic pathway plays a central role in the reward system, the genes involved in this pathway are thought to be susceptibility genes for addictive disorders. Indeed, a number of studies have identified polymorphisms in this pathway that infer susceptibility to addiction: genetic variations in the DRD2, DRD3, COMT and DAT1 genes have been reported to associate with smoking, alcoholism, cocaine abuse and heroin addiction [92-101]. Nevertheless, despite the large number of studies reporting association, meta-analyses have shown that the effects are only weak or not significant $[102,103]$.

\section{Fetal Alcohol Syndrome}

During pregnancy, alcohol use by the mother may lead to fetal alcohol syndrome (FAS) that occurs at a rate of 0.5-2 individuals per 1000 live births. A number of family, twin and animal studies have suggested a genetic component in FAS pathogenesis, one of the main candidate genes being the alcohol dehydrogenase 1B (ADH1B) gene located on chromosome 4q21-q23. However, whereas some studies report a protective effect for a number of ADH1B subtypes, others were not successful in reproducing these results [reviewed in 104]. Besides ADH1B, other candidate genes have been suggested as risk factors for FAS pathogenesis, such as the cytochrome P450 2E1 gene (CYP2E1; 10q24.3-qter) [105, 106].

\section{Anxiety Disorders}

Panic disorder, OCD, separation anxiety, overanxious disorder, agoraphobia and other phobias all belong to the group of anxiety disorders and are relatively common (lifetime prevalence of $25 \%$ [107]). Twin studies have indicated that a genetic factor is involved in anxiety disorders, but the genetic contribution to the disorders is only modest (3040\%) [108]. Yet, many linkage and association studies have been performed to determine the chromosomal locations or genes involved in the pathogenesis of the various subtypes of anxiety disorders. Panic disorder showed significant linkage to chromosomal regions $9 \mathrm{q} 31,13 \mathrm{q}$ and $22 \mathrm{q}[109,110]$, for OCD linkage was reported to chromosome 1q, 3q27-28, 6q, $7 \mathrm{p}, 9 \mathrm{p} 24,10 \mathrm{p} 15,14$ and 15q [111-114], and for other anxiety disorders linkage was observed for chromosome $14 \mathrm{p}$ (simple phobia) [115], 16 (social phobia) [116], 1q, 4q, 7p, 12q and $13 q$ (neuroticism) [117] and 8p21-23 (harm avoidance) [118]. Recently, also genome-wide linkage analyses on individuals with a broad anxiety phenotype rather than based on the DSM-IV anxiety disorder diagnosis have been performed and significant linkage was observed for chromosome 14 [119] and 4q31-q34 [120].

Besides linkage analysis, many case-control design studies on candidate genes for anxiety pathogenesis have been performed. For panic disorder, a positive association was found for the serotonin receptors HTR1A (5q11.2-q13) and HTR2A (13q14-q21) [121, 122], COMT [123], the neuropeptide cholecystokinin (CCK; 3p22-p21.3) [124], the adenosine A2a receptor (ADORA2A; 22q11.23) [125], MAOA [126], the nuclear transcription factor cAMP-responsive element modulator (CREM; 10p11.21) [127], the peripheral benzodiazepine receptor (PBR or TSPO; 22q13.31) [128], glutamic acid decarboxylase 1 (GAD1; 2q31) [129], diazepam binding inhibitor (DBI; 2q12-q21) [130], calmodulin- 
dependent protein kinase kinase $b$ (CaMKKb; 12q24.2) [131] and angiotensin-converting enzyme (ACE; 17q23.3) [132]. In addition, an association analysis of 90 SNPs located in 21 candidate genes revealed eight SNPs to be associated with panic disorder (located in the CCK, serotonin and dopamine systems), but all with a minor individual effect [133].

Besides association with panic disorder, a number of susceptibility genes have been found to associate with other subtypes within anxiety disorders as well, such as the serotonin system in OCD and neuroticism [134-139], MAOA in generalized anxiety disorder and neuroticism [140, 141], COMT in neuroticism and phobic anxiety [141, 142] and BDNF in anxiety-related personality traits [143, 144].

\section{Posttraumatic Stress Disorder}

Posttraumatic stress disorder (PTSD) can occur in a subset of individuals exposed to extreme traumatic events [145], and has a lifetime incidence of $\sim 9-15 \%$ [146, 147], and an estimated genetic inheritance of $\sim 30 \%$ [148]. Susceptibility genes for PTSD have not yet been identified, but to date the number of individuals screened is low, while the few genetic studies that have been performed mainly focussed on key candidate genes, including BDNF, neuropeptide Y (NPY; $7 \mathrm{p} 15.1)$, the glucocorticoid receptor (NR3C1; 5q31.3), and components of the serotonin and dopamine pathways [149153].

\section{Eating Disorders}

Anorexia and bulimia nervosa are two major eating disorders with still unknown risk factors. For a long time, eating disorders have been considered to be caused by sociocultural factors. However, it has recently become clear that also genetics may play a substantial role in its aetiology. Family and twin studies have shown that heritability estimates for eating disorders vary from $48 \%$ to $74 \%$ in anorexia nervosa and from $55 \%$ to $83 \%$ in bulimia nervosa [154-157]. Since serotonin plays an important role in mood and feeding, genetic variations in the serotonergic pathway are thought to lead to eating disturbances. Indeed, a number of positive associations with the serotonin receptors HTR2A and HTR2C (Xq24), and also with the serotonin transporter gene have been reported [158-160], however, replication was not always successful [161, 162]. Furthermore, associations were found for BDNF [163, 164], the growth hormone secretagogue receptor (ghrelin receptor or GHSR; 3q26.31) [165] and COMT [166, 167].

\section{Spina Bifida}

Spina bifida is caused by unsuccessful closure of the neural tube during early development (between embryonic day 17 and 30) and occurs with a frequency of 1-2 cases per 1000 births. The exact aetiology of spina bifida is poorly understood, but it is clear that both genetic and environmental factors are involved [168]. Since individuals with spina bifida often die prenatal or early postnatal and thus hardly any families exist with several affected members, this disease could well be the most difficult complex disorder to study at the genetic level. Based on animal and epidemiological studies, genes involved in folic acid (folate), vitamin
B12 and homocysteine metabolism, or genes involved in neurulation have been hypothesized to play a role in spina bifida genesis [reviewed in 169]. However, until now, only a few genes have been reported to represent risk factors for spina bifida, including 5,10-methylenetetrahydrofolate reductase (MTHFR; 1p36.3) [170], methionine synthase reductase (MTRR; 5p15.3-p15.2) [171], platelet-derived growth factor receptor alpha (PDGFRA; 4q11-q13) [172] endothelial nitric oxide synthase 3 (NOS3; 7q36) [173] protein-Lisoaspartate (D-aspartate) O-methyltransferase (PCMT1; 6q24-q25) [174] and cofilin 1 (non-muscle) (CFL1; 11q13) [175].

\section{Hydrocephalus}

Hydrocephalus occurs at a frequency of approximately 0.5 in 1000 births [176, 177] and is characterized by abnormal flow or resorption of cerebrospinal fluid. It is considered a heterogeneous complex disorder [178] with genetic and environmental aetiologies [179, 180]. Although approximately $37 \%$ of the hydrocephalus cases have a possible genetic aetiology [180], clear susceptibility genes for hydrocephalus have not been identified yet. Studies in animal models have suggested several loci as susceptibility regions for hydrocephalus, but these regions have not yet been reported as susceptibility regions in human [reviewed in 181].

\section{COMPLEX NEURODEVELOPMENTAL DISORDERS AND THE ENVIRONMENT}

Since in general complex neurodevelopmental disorders have an estimated heritability lower than $100 \%$ (Table 2), their aetiology includes another component that is thought to be primarily the environment (e.g. stressful life events). $\mathrm{Nu}$ merous factors acting during early development of a foetus may contribute to the genesis of a neurodevelopmental disorder, including insufficient maternal nutrition, daily smoking, viral infection and repeated psychological stress [182]. Most environmental vulnerability factors are however difficult to assign and quantify.

The type and timing of the early environmental risk factors to which an organism is exposed appear to determine the phenotypic outcome. For example, a prenatal exposure of 9days-pregnant mice to a sublethal intranasal administration of influenza virus led to both short-term and long-lasting deleterious effects on the developing brain structures and to abnormal behavior in the offspring of the mice [183]. Besides risk factors during early (prenatal) development, also obstetrical complications, including the use of resuscitation or an incubator, premature membrane rupture, diabetes, rhesus incompatibility, bleeding, preterm birth or caesarean birth, may increase the vulnerability to neurodevelopmental disorders [184, 185].

One obvious gene-environment link concerns the season in which birth took place. An excess of winter-spring births in bipolar disorder and schizophrenia has been observed [186]. A similar tendency has been found in schizoaffective disorder (December-March), major depression (March-May) and autism (March) [reviewed in 187]. Besides the season of birth, also the place of birth is thought to be associated. Urban-born (and brought-up) subjects are more susceptible to neurodevelopmental disorders than rural-born (and brought- 
up) subjects [188]. Furthermore, risk factors like immigration and adoption may contribute to the development of psychiatric disorders [189, 190].

\section{GENE-ENVIRONMENT INTERACTIONS IN COM- PLEX NEURODEVELOPMENTAL DISORDERS}

One of the reasons that the genetic and environmental factors in complex neurodevelopmental disorders are difficult to define is the fact that the two factors may interact. However, such an interaction may be complex and act at various levels. For instance, genetic and environmental factors may have an additive effect, genetic factors may affect the influence of the environment on a phenotype or environmental factors may modulate the expression of genetic variants.

An example of a gene-environment interaction concerns the influence of stressful life events on depressive individuals with a functional polymorphism in the promoter region of the serotonin transporter gene. Individuals with the short allele have been found to respond differently to stressful life events (e.g. childhood maltreatment) and as such are more vulnerable to develop depressive symptoms than individuals with the long allele [29]. A second example of geneenvironment interaction is the valine/methionine polymorphism (SNP rs4680) in the COMT gene. Upon cannabis use, individuals carrying the valine allele have a higher chance to exhibit psychotic symptoms and to develop schizophreniform disorders when compared to individuals with two methionine alleles [191].

\section{COMPLEX NEURODEVELOPMENTAL DISORDERS AND EPIGENETICS}

Epigenetics is defined as heritable changes in gene expression patterns that occur without changing the DNA sequence itself [192], and includes DNA methylation and posttranslational modifications of histone proteins. DNA methylation, i.e. a covalent binding of a methyl group to the 5position of the cytosine ring within the sequence 5 ' $-\mathrm{CG}-3$ ' $(\mathrm{CpG})$, can be tissue- and cell-type specific and is found in all vertebrates, and many invertebrates and plants. $\mathrm{CpG}$ clusters with a minimum of 200 base pairs, a CG percentage greater than $50 \%$ and an observed/expected $\mathrm{CpG}$ ratio greater than 0.6 are called $\mathrm{CpG}$ islands. These islands are often found in gene promoter regions and can protect single CpGs within a $\mathrm{CpG}$ island from DNA methylation.

An apparent link between the methylation status and gene transcription levels has led to the speculation that alterations in the methylation pattern (epimutations) might contribute to altered gene expression. Such epimutations are thought to occur upon exposure to environmental risk factors, including early developmental stress. Since early embryos seem to be particularly sensitive to epimutations [193, 194], this factor should be considered for the aetiology of neurodevelopmental disorders. For instance, epigenetic alterations are responsible for a number of neurodevelopmental disorders with single-gene defects, such as Rett Syndrome, ICF Syndrome, Fragile X Syndrome and ATR-X Syndrome [195-198]. A role for DNA methylation has also been proposed in connection with complex neurodevelopmental disorders. For example, spina bifida can be caused by a lack of folate [reviewed in 199], a compound needed for the generation of S-adenosylmethionine (SAM) that donates the methyl group in the DNA methylation process. Also, some patients with depressive illness and schizophrenia display lower serum folate levels [200]. Animal models further provide evidence for a possible link between epigenetics and neurodevelopmental disorders. Following a diet with Lmethionine, a precursor in the biosynthesis of SAM, the reeler mouse (a model for schizophrenia) showed increased promoter methylation of the reelin gene, reduced reelin expression and a declined prepulse inhibition of startle. These effects could subsequently be reversed by valproic acid, a mood-stabilizing drug used for treatment of epilepsy, bipolar disorder and schizophrenia [201]. In addition, the adult offspring of rat mothers that showed high licking and grooming (LG) and arched-back nursing (ABN) (two forms of maternal behaviour in the rat that serve as the basis for the individuals programming of the stress response) are less fearful, have a lower hypothalamic-pituitary-adrenal response to stress, and have a lower DNA methylation status in the promoter region of the glucocorticoid receptor gene when compared to the offspring of low-LG and -ABN mothers [202]. Thus, alterations in epigenetic profiles may contribute to the generation of complex neurodevelopmental disorders.

\section{COMPLICATING FACTORS IN ASSOCIATION STUDIES}

Although numerous studies suggest that genetic variants play a significant role in the aetiology of complex neurodevelopmental disorders, in almost all cases the precise genetic background remains to be identified. Several factors (see below) have greatly complicated the identification of the genetic basis of neurodevelopmental disorders.

\section{Definition of Phenotype}

In the genetics of psychiatric disorders, the definition of a phenotype is one of the main problems. Most genetic studies use patient characterization according to the DSM-IV or ICD-10 criteria. However, investigators nowadays believe that the phenotype should be specified in more detail, since most neurodevelopmental disorders include a number of intermediate clinical subtypes and distinct phenotypical parameters (endophenotypes) [203], presumably each with a different genetic background. Such endophenotypes may help in the identification of risk factors, although the effectiveness of this approach has recently been questioned [204]. Nevertheless, analysis of an endophenotypically defined group of patients may increase replication efficacy.

\section{Population Stratification}

Genetic variations often occur among (geographically or ethnically) different populations and this fact may thus increase the difficulty in data interpretation as well. For correct stratification and successful replication, it is therefore highly important that samples are clinically, geographically and ethnically well characterized.

\section{Gene-Environment Interactions}

Another complicating factor in the identification of susceptibility genes for neurodevelopmental disorders concerns 
the possibility of multifactorial gene-plus-environment interactions, as mentioned above. Unfortunately, such interactions are still difficult to quantify and interpret.

\section{Multiple Genes Hypothesis}

The search for susceptibility genes is further complicated when the aetiology of a complex neurodevelopmental disorder can not be explained by a single genetic variant with a relatively large effect but is rather caused by an interplay of a number of genes with small (additive) effects. For schizophrenia pathogenesis, the essential parameters for single- and multiple-locus models have been calculated and an interaction of about three different genes together with the environment was predicted to underly this disorder [205]. Not surprisingly, in general the greater the number of genes involved the more difficult their identification will be and larger (or additional) cohorts will be necessary to reach significant association. In addition, besides the possibility that multiple susceptibility genes are involved, individuals may be affected by the absence of protective alleles, while epistasis may also play a role.

\section{Common Disease-Common Variant or Rare-Variant Hy- pothesis}

At present, it is not clear whether only a relatively small number of common genetic variants are linked to the aetiology of neurodevelopmental disorders (known as the "common disease-common variant hypothesis", often abbreviated CD-CV) [206, 207], or if a large number of rare genetic variants is involved ("rare-variant-hypothesis" or heterogeneity hypothesis) [208]. In case of CD-CV, association analyses (e.g. GWA studies) may detect genetic variants if the studies contain enough power. It is clear that association analyses will be more difficult in rare variant cases [209].

\section{CONCLUSIONS AND FUTURE DIRECTIONS}

Our summary of the current knowledge of the genetic, environmental and epigenetic contribution to the aetiology of neurodevelopmental disorders illustrates that unravelling the pathogenesis of these disorders is highly complex. Although further insights into the degree of the genetic contribution to the aetiology of neurodevelopmental disorders has been obtained, the identities of the genes involved and thus diagnostic markers are mostly lacking.

Up to now, in general, a presumptive susceptibility gene appears to be linked to a single neurodevelopmental disorder. However, the existence of a single susceptibility gene for both schizophrenia and bipolar disorder [reviewed in 21, 24] illustrates that we probably have to await the results of future genetic research for a definitive conclusion concerning this issue. The future results will also reveal which pathways are involved in the complex disorders.

For a better understanding of the aetiologies involved, it will be fruitful to obtain detailed clinical, ethnical and geographical information on large groups of individuals. In addition, the environmental factors need to be well defined and documented. However, until now our knowledge of the relevant environmental risk factors is rather limited. Clearly, close collaborations between psychiatrists and genetic researchers are required.
Undoubtedly, in the near future many more GWA studies with the $500 \mathrm{~K}$ and even larger SNP arrays will be reported. Such studies will however not cover all genetic variations in the genome [210], because SNPs with a low minor allele frequency (MAF) $(<0.05)$ are usually not included on the arrays, thereby excluding analysis of rare genetic variants. This is unfortunate, since the rare genetic variants are generally considered to have a higher chance of being causative [211]. Thus, candidate gene approaches of selected SNPs with a low prevalence may increase the chances to identify functional genetic variants. Because one would expect that causal SNPs have an effect in any population, a further consideration may involve a choice of SNPs with a low MAF in all ethnical populations. In this connection, one has to be aware of the possibility that such a SNP may need an additional polymorphism(s) to explain the phenotype (multiple genes hypothesis), while the additional genetic variation(s) may not be present in a particular ethnical population. One of the practical problems in dealing with low-MAF SNPs concerns the sample size necessary to obtain reliable association data, i.e. the lower the MAF the more samples are required to reach statistical significance. It is likely that inclusion of potentially functional SNPs (non-synonymous SNPs and SNPs in gene promoter regions or exon-intron boundaries) will increase the success rate in the analysis. At present, chips containing 20,000 non-synonymous human SNPs from $\sim 11,000$ genes are already available (www.affymetrix.com).

This review has attempted to provide an overview of the aetiologies of complex neurodevelopmental disorders. Clearly, many questions remain unanswered with respect to the pathogenesis of such disorders. Nevertheless, it is to be expected that within the next years the tsunami of genetic research will lead to more insights into the susceptibility genes. This new information can then be applied to start new research strategies, including the use of genetically manipulated cells or animal model systems carrying the susceptibility gene for functional studies on the pathways involved. Eventually, the acquired understanding of the molecular mechanisms underlying complex disorders may lead to translational research, including the design of gene/pathwayspecific drugs and the application of disease-preventing strategies.

\section{ACKNOWLEDGEMENT}

We thank the Dutch Top Institute Pharma for support (project number T5-209).

\section{ABBREVIATIONS}

\begin{tabular}{|c|c|c|}
\hline $\mathrm{ABN}$ & $=$ & Arched-back nursing \\
\hline ADH1B & $=$ & Alcohol dehydrogenase 1B \\
\hline ADHD & $=$ & Attention deficit hyperactivity disorder \\
\hline ATR-X & $=$ & $\begin{array}{l}\text { X-linked alpha thalassemia/mental } \\
\text { retardation }\end{array}$ \\
\hline BDNF & $=$ & Brain-derived neurotrophic factor \\
\hline $\mathrm{CCK}$ & $=$ & Cholecystokinin \\
\hline $\mathrm{CD}-\mathrm{CV}$ & $=$ & Common disease-common variant \\
\hline $\mathrm{CGH}$ & $=$ & Comparative genome hybridization \\
\hline
\end{tabular}




\begin{tabular}{|c|c|c|}
\hline CNV & $=$ & Copy-number variants \\
\hline COMT & $=$ & Catechol-O-methyl transferase \\
\hline CSNK1G2 & $=$ & Casein kinase I gamma 2 isoform \\
\hline DAO & $=$ & D-amino-acid oxidase \\
\hline DAOA & $=$ & D-amino acid oxidase activator \\
\hline DAT & $=$ & Dopamine transporter \\
\hline DISC1 & $=$ & Disrupted in schizophrenia 1 \\
\hline DRD2 & $=$ & Dopamine receptor D2 \\
\hline DRD3 & $=$ & Dopamine receptor D3 \\
\hline DRD4 & $=$ & Dopamine receptor D4 \\
\hline DSM & $=$ & $\begin{array}{l}\text { Diagnostic and Statistical manual for mental } \\
\text { disorders }\end{array}$ \\
\hline FAS & $=$ & Fetal alcohol syndrome \\
\hline FMR1 & $=$ & Fragile X mental retardation 1 \\
\hline FS & $=$ & Febrile seizures \\
\hline GWA & $=$ & Genome-wide association \\
\hline HTR2A & $=$ & 5-hydroxytryptamine (serotonin) receptor $2 \mathrm{~A}$ \\
\hline ICD & $=$ & International Classification of Disease \\
\hline ICF & $=$ & $\begin{array}{l}\text { Immunodeficiency, centromeric region } \\
\text { instability, facial anomalies }\end{array}$ \\
\hline IMPA2 & $=$ & Inositol(myo)-1(or 4)-monophosphatase 2 \\
\hline LG & $=$ & Licking and grooming \\
\hline MAF & $=$ & Minor allele frequency \\
\hline MAOA & $=$ & Monoamine oxidase A \\
\hline $\mathrm{MeCP} 2$ & $=$ & Methyl CpG binding protein 2 \\
\hline MR & $=$ & Mental retardation \\
\hline NRG1 & $=$ & Neuregulin-1 \\
\hline OCD & $=$ & Obsessive-compulsive disorder \\
\hline PDD & $=$ & Pervasive developmental disorders \\
\hline PTSD & $=$ & Posttraumatic stress disorder \\
\hline RGS4 & $=$ & Regulator of G-protein signalling 4 \\
\hline SAM & $=$ & S-adenosylmethionine \\
\hline SLC6A4 & $=$ & Serotonin transporter \\
\hline SNP & $=$ & Single-nucleotide polymorphism \\
\hline
\end{tabular}

\section{REFERENCES}

[1] Risch, N., Merikangas, K. The future of genetic studies of complex human diseases. Science 1996, 273: 1516-7.

[2] Craddock, N., Owen, M.J. Modern molecular genetic approaches to psychiatric disease. Br. Med. Bull. 1996, 52: 434-52.

[3] Owen, M.J., Craddock, N. Modern molecular genetic approaches to complex traits: implications for psychiatric disorders. Mol. Psychiatry 1996, 1: 21-6.

[4] Risch, N.J. Searching for genetic determinants in the new millennium. Nature 2000, 405: 847-56.

[5] Lee, J.A., Lupski, J.R. Genomic rearrangements and gene copynumber alterations as a cause of nervous system disorders. Neuron 2006, 52: 103-21.

[6] Redon, R., Ishikawa, S., Fitch, K.R., Feuk, L., Perry, G.H., Andrews, T.D., Fiegler, H., Shapero, M.H., Carson, A.R., Chen, W.,
Cho, E.K., Dallaire, S., Freeman, J.L., Gonzalez, J.R., Gratacos, M., Huang, J., Kalaitzopoulos, D., Komura, D., MacDonald, J.R., Marshall, C.R., Mei, R., Montgomery, L., Nishimura, K., Okamura, K., Shen, F., Somerville, M.J., Tchinda, J., Valsesia, A., Woodwark, C., Yang, F., Zhang, J., Zerjal, T., Zhang, J., Armengol, L., Conrad, D.F., Estivill, X., Tyler-Smith, C., Carter, N.P., Aburatani, H., Lee, C., Jones, K.W., Scherer, S.W., Hurles, M.E. Global variation in copy number in the human genome. Nature 2006, 444: 44454.

[7] Tkachev, D., Mimmack, M.L., Ryan, M.M., Wayland, M., Freeman, T., Jones, P.B., Starkey, M., Webster, M.J., Yolken, R.H., Bahn, S. Oligodendrocyte dysfunction in schizophrenia and bipolar disorder. Lancet 2003, 362: 798-805.

[8] Montes, G., Halterman, J.S. Characteristics of school-age children with autism. J. Dev. Behav. Pediatr. 2006, 27: 379-85.

[9] Freitag, C.M. The genetics of autistic disorders and its clinical relevance: a review of the literature. Mol. Psychiatry 2007, 12: 222.

[10] Yang, M.S., Gill, M. A review of gene linkage, association and expression studies in autism and an assessment of convergent evidence. Int. J. Dev. Neurosci. 2007, 25: 69-85.

[11] Lauritsen, M.B., Als, T.D., Dahl, H.A., Flint, T.J., Wang, A.G., Vang, M., Kruse, T.A., Ewald, H., Mors, O. A genome-wide search for alleles and haplotypes associated with autism and related pervasive developmental disorders on the Faroe Islands. Mol. Psychiatry 2006, 11: 37-46.

[12] Szatmari, P., Paterson, A.D., Zwaigenbaum, L., Roberts, W., Brian, J., Liu, X.Q., Vincent, J.B., Skaug, J.L., Thompson, A.P., Senman, L., Feuk, L., Qian, C., Bryson, S.E., Jones, M.B., Marshall, C.R., Scherer, S.W., Vieland, V.J., Bartlett, C., Mangin, L.V., Goedken, R., Segre, A., Pericak-Vance, M.A., Cuccaro, M.L., Gilbert, J.R., Wright, H.H., Abramson, R.K., Betancur, C., Bourgeron, T., Gillberg, C., Leboyer, M., Buxbaum, J.D., Davis, K.L., Hollander, E., Silverman, J.M., Hallmayer, J., Lotspeich, L., Sutcliffe, J.S., Haines, J.L., Folstein, S.E., Piven, J., Wassink, T.H., Sheffield, V., Geschwind, D.H., Bucan, M., Brown, W.T., Cantor, R.M., Constantino, J.N., Gilliam, T.C., Herbert, M., Lajonchere, C., Ledbetter, D.H., Lese-Martin, C., Miller, J., Nelson, S., Samango-Sprouse, C.A., Spence, S., State, M., Tanzi, R.E., Coon, H., Dawson, G., Devlin, B., Estes, A., Flodman, P., Klei, L., McMahon, W.M., Minshew, N., Munson, J., Korvatska, E., Rodier, P.M., Schellenberg, G.D., Smith, M., Spence, M.A., Stodgell, C., Tepper, P.G., Wijsman, E.M., Yu, C.E., Roge, B., Mantoulan, C., Wittemeyer, K., Poustka, A., Felder, B., Klauck, S.M., Schuster, C., Poustka, F., Bolte, S., Feineis-Matthews, S., Herbrecht, E., Schmotzer, G., Tsiantis, J., Papanikolaou, K., Maestrini, E., Bacchelli, E., Blasi, F., Carone, S., Toma, C., Van Engeland, H., de Jonge, M., Kemner, C., Koop, F., Langemeijer, M., Hijimans, C., Staal, W.G., Baird, G., Bolton, P.F., Rutter, M.L., Weisblatt, E., Green, J., Aldred, C., Wilkinson, J.A., Pickles, A., Le Couteur, A., Berney, T., McConachie, H., Bailey, A.J., Francis, K., Honeyman, G., Hutchinson, A., Parr, J.R., Wallace, S., Monaco, A.P., Barnby, G., Kobayashi, K., Lamb, J.A., Sousa, I., Sykes, N., Cook, E.H., Guter, S.J., Leventhal, B.L., Salt, J., Lord, C., Corsello, C., Hus, V., Weeks, D.E., Volkmar, F., Tauber, M., Fombonne, E., Shih, A. Mapping autism risk loci using genetic linkage and chromosomal rearrangements. Nat. Genet. 2007, 39: 319-28.

[13] Sebat, J., Lakshmi, B., Malhotra, D., Troge, J., Lese-Martin, C., Walsh, T., Yamrom, B., Yoon, S., Krasnitz, A., Kendall, J., Leotta, A., Pai, D., Zhang, R., Lee, Y.H., Hicks, J., Spence, S.J., Lee, A.T., Puura, K., Lehtimaki, T., Ledbetter, D., Gregersen, P.K., Bregman, J., Sutcliffe, J.S., Jobanputra, V., Chung, W., Warburton, D., King, M.C., Skuse, D., Geschwind, D.H., Gilliam, T.C., Ye, K., Wigler, M. Strong association of de novo copy number mutations with autism. Science 2007, 316: 445-9.

[14] Jablensky, A., Sartorius, N., Korten, A., Ernberg, G., Anker, M., Cooper, J.E., Day, R. Incidence worldwide of schizophrenia. Br. J. Psychiatry 1987, 151: 408-9.

[15] Kay, S.R., Opler, L.A. The positive-negative dimension in schizophrenia: its validity and significance. Psychiatr. Dev. 1987, 5: 79103.

[16] Gottesman, I. Schizophrenia genesis: The origins of madness. New York: W.H. Freeman and Company; 1991.

[17] Cardno, A.G., Marshall, E.J., Coid, B., Macdonald, A.M., Ribchester, T.R., Davies, N.J., Venturi, P., Jones, L.A., Lewis, S.W., Sham, P.C., Gottesman, II, Farmer, A.E., McGuffin, P., Reveley, A.M., 
Murray, R.M. Heritability estimates for psychotic disorders: the Maudsley twin psychosis series. Arch. Gen. Psychiatry 1999, 56: 162-8.

[18] Ross, C.A., Margolis, R.L., Reading, S.A., Pletnikov, M., Coyle, J.T. Neurobiology of schizophrenia. Neuron 2006, 52: 139-53.

[19] Owen, M.J., Craddock, N., O'Donovan, M.C. Schizophrenia: genes at last? Trends Genet. 2005, 21: 518-25.

[20] Lencz, T., Morgan, T.V., Athanasiou, M., Dain, B., Reed, C.R., Kane, J.M., Kucherlapati, R., Malhotra, A.K. Converging evidence for a pseudoautosomal cytokine receptor gene locus in schizophrenia. Mol. Psychiatry 2007, 12: 572-80.

[21] Kato, T. Molecular genetics of bipolar disorder and depression. Psychiatry Clin. Neurosci. 2007, 61: 3-19.

[22] Smoller, J.W., Finn, C.T. Family, twin, and adoption studies of bipolar disorder. Am. J. Med. Genet. C Semin. Med. Genet. 2003, 123: 48-58.

[23] Berrettini, W. Evidence for shared susceptibility in bipolar disorder and schizophrenia. Am. J. Med. Genet. C Semin. Med. Genet. 2003, 123: 59-64.

[24] Farmer, A., Elkin, A., McGuffin, P. The genetics of bipolar affective disorder. Curr. Opin. Psychiatry 2007, 20: 8-12.

[25] Genome-wide association study of 14,000 cases of seven common diseases and 3,000 shared controls. Nature 2007, 447: 661-78.

[26] Kessler, R.C., Berglund, P., Demler, O., Jin, R., Koretz, D., Merikangas, K.R., Rush, A.J., Walters, E.E., Wang, P.S. The epidemiology of major depressive disorder: results from the National Comorbidity Survey Replication (NCS-R). JAMA 2003, 289: 3095105 .

[27] Kendler, K.S., Karkowski-Shuman, L. Stressful life events and genetic liability to major depression: genetic control of exposure to the environment? Psychol. Med. 1997, 27: 539-47.

[28] Massat, I., Souery, D., Del-Favero, J., Nothen, M., Blackwood, D., Muir, W., Kaneva, R., Serretti, A., Lorenzi, C., Rietschel, M., Milanova, V., Papadimitriou, G.N., Dikeos, D., Van Broekhoven, C., Mendlewicz, J. Association between COMT (Val158Met) functional polymorphism and early onset in patients with major depressive disorder in a European multicenter genetic association study. Mol. Psychiatry 2005, 10: 598-605.

[29] Caspi, A., Sugden, K., Moffitt, T.E., Taylor, A., Craig, I.W., Harrington, H., McClay, J., Mill, J., Martin, J., Braithwaite, A., Poulton, R. Influence of life stress on depression: moderation by a polymorphism in the 5-HTT gene. Science 2003, 301: 386-9.

[30] Schumacher, J., Jamra, R.A., Becker, T., Ohlraun, S., Klopp, N., Binder, E.B., Schulze, T.G., Deschner, M., Schmal, C., Hofels, S., Zobel, A., Illig, T., Propping, P., Holsboer, F., Rietschel, M., Nothen, M.M., Cichon, S. Evidence for a relationship between genetic variants at the brain-derived neurotrophic factor (BDNF) locus and major depression. Biol. Psychiatry 2005, 58: 307-14.

[31] Surtees, P.G., Wainwright, N.W., Willis-Owen, S.A., Sandhu, M.S., Luben, R., Day, N.E., Flint, J. No association between the BDNF Val66Met polymorphism and mood status in a non-clinical community sample of 7389 older adults. J. Psychiatr. Res. 2007, 41: 404-9.

[32] Gillespie, N.A., Whitfield, J.B., Williams, B., Heath, A.C., Martin, N.G. The relationship between stressful life events, the serotonin transporter (5-HTTLPR) genotype and major depression. Psychol. Med. 2005, 35: 101-11.

[33] Frisch, A., Postilnick, D., Rockah, R., Michaelovsky, E., Postilnick, S., Birman, E., Laor, N., Rauchverger, B., Kreinin, A., Poyurovsky, M., Schneidman, M., Modai, I., Weizman, R. Association of unipolar major depressive disorder with genes of the serotonergic and dopaminergic pathways. Mol. Psychiatry 1999, 4: 389-92.

[34] Comings, D.E. Clinical and molecular genetics of ADHD and Tourette syndrome. Two related polygenic disorders. Ann. N. Y. Acad. Sci. 2001, 931: 50-83

[35] Faraone, S.V., Sergeant, J., Gillberg, C., Biederman, J. The worldwide prevalence of ADHD: is it an American condition? World Psychiatry 2003, 2: 104-113.

[36] Faraone, S.V., Khan, S.A. Candidate gene studies of attentiondeficit/hyperactivity disorder. J. Clin. Psychiatry 2006, 67 Suppl 8: 13-20.

[37] Brookes, K., Xu, X., Chen, W., Zhou, K., Neale, B., Lowe, N., Anney, R., Franke, B., Gill, M., Ebstein, R., Buitelaar, J., Sham, P., Campbell, D., Knight, J., Andreou, P., Altink, M., Arnold, R., Boer, F., Buschgens, C., Butler, L., Christiansen, H., Feldman, L.,
Fleischman, K., Fliers, E., Howe-Forbes, R., Goldfarb, A., Heise, A., Gabriels, I., Korn-Lubetzki, I., Johansson, L., Marco, R., Medad, S., Minderaa, R., Mulas, F., Muller, U., Mulligan, A., Rabin, K., Rommelse, N., Sethna, V., Sorohan, J., Uebel, H., Psychogiou, L., Weeks, A., Barrett, R., Craig, I., Banaschewski, T., Sonuga-Barke, E., Eisenberg, J., Kuntsi, J., Manor, I., McGuffin, P., Miranda, A., Oades, R.D., Plomin, R., Roeyers, H., Rothenberger, A., Sergeant, J., Steinhausen, H.C., Taylor, E., Thompson, M., Faraone, S.V., Asherson, P. The analysis of 51 genes in DSMIV combined type attention deficit hyperactivity disorder: association signals in DRD4, DAT1 and 16 other genes. Mol. Psychiatry 2006, 11: 934-53.

[38] Robertson, M.M. Diagnosing Tourette syndrome: is it a common disorder? J. Psychosom. Res. 2003, 55: 3-6.

[39] Pauls, D.L. An update on the genetics of Gilles de la Tourette syndrome. J. Psychosom. Res. 2003, 55: 7-12.

[40] Grice, D.E., Leckman, J.F., Pauls, D.L., Kurlan, R., Kidd, K.K., Pakstis, A.J., Chang, F.M., Buxbaum, J.D., Cohen, D.J., Gelernter, J. Linkage disequilibrium between an allele at the dopamine D4 receptor locus and Tourette syndrome, by the transmissiondisequilibrium test. Am. J. Hum. Genet. 1996, 59: 644-52.

[41] Tarnok, Z., Ronai, Z., Gervai, J., Kereszturi, E., Gadoros, J., Sasvari-Szekely, M., Nemoda, Z. Dopaminergic candidate genes in Tourette syndrome: Association between tic severity and 3' UTR polymorphism of the dopamine transporter gene. Am. J. Med. Genet. B Neuropsychiatr. Genet. 2007, 144: 900-5.

[42] Comings, D.E., Comings, B.G., Muhleman, D., Dietz, G., Shahbahrami, B., Tast, D., Knell, E., Kocsis, P., Baumgarten, R., Kovacs, B.W., Levy, D.L., Smith, M., Kane, J.M., Lieberman, J.A., KLein, D.N., MacMurray, J., Tosk, J., Sverd, J., Gysin, R., Flanagan, S. The dopamine D2 receptor locus as a modifying gene in neuropsychiatric disorders. Jama 1991, 266: 1793-800.

[43] Yoon, D.Y., Rippel, C.A., Kobets, A.J., Morris, C.M., Lee, J.E., Williams, P.N., Bridges, D.D., Vandenbergh, D.J., Shugart, Y.Y., Singer, H.S. Dopaminergic polymorphisms in Tourette syndrome: association with the DAT gene (SLC6A3). Am. J. Med. Genet. B Neuropsychiatr. Genet. 2007, 144: 605-10.

[44] Comings, D.E., Muhleman, D., Dietz, G., Dino, M., LeGro, R., Gade, R. Association between Tourette's syndrome and homozygosity at the dopamine D3 receptor gene. Lancet 1993, 341: 906.

[45] Rowe, D.C., Stever, C., Gard, J.M., Cleveland, H.H., Sanders, M.L., Abramowitz, A., Kozol, S.T., Mohr, J.H., Sherman, S.L., Waldman, I.D. The relation of the dopamine transporter gene (DAT1) to symptoms of internalizing disorders in children. Behav. Genet. 1998, 28: 215-25.

[46] Comings, D.E., Wu, S., Chiu, C., Ring, R.H., Gade, R., Ahn, C., MacMurray, J.P., Dietz, G., Muhleman, D. Polygenic inheritance of Tourette syndrome, stuttering, attention deficit hyperactivity, conduct, and oppositional defiant disorder: the additive and subtractive effect of the three dopaminergic genes--DRD2, D beta $\mathrm{H}$ and DAT1. Am. J. Med. Genet. 1996, 67: 264-88.

[47] Gade, R., Muhleman, D., Blake, H., MacMurray, J., Johnson, P., Verde, R., Saucier, G., Comings, D.E. Correlation of length of VNTR alleles at the X-linked MAOA gene and phenotypic effect in Tourette syndrome and drug abuse. Mol. Psychiatry 1998, 3: 50-60.

[48] Gelernter, J., Pakstis, A.J., Pauls, D.L., Kurlan, R., Gancher, S.T., Civelli, O., Grandy, D., Kidd, K.K. Gilles de la Tourette syndrome is not linked to D2-dopamine receptor. Arch. Gen. Psychiatry 1990, 47: 1073-7.

[49] Gelernter, J., Kennedy, J.L., Grandy, D.K., Zhou, Q.Y., Civelli, O., Pauls, D.L., Pakstis, A., Kurlan, R., Sunahara, R.K., Niznik, H.B., O'Dowd, B., Seeman, P., Kidd, K.K. Exclusion of close linkage of Tourette's syndrome to D1 dopamine receptor. Am. J. Psychiatry 1993, 150: 449-53.

[50] Barr, C.L., Wigg, K.G., Zovko, E., Sandor, P., Tsui, L.C. No evidence for a major gene effect of the dopamine D4 receptor gene in the susceptibility to Gilles de la Tourette syndrome in five Canadian families. Am. J. Med. Genet. 1996, 67: 301-5.

[51] Brett, P., Robertson, M., Gurling, H., Curtis, D. Failure to find linkage and increased homozygosity for the dopamine D3 receptor gene in Tourette's syndrome. Lancet 1993, 341: 1225

[52] Barr, C.L., Wigg, K.G., Zovko, E., Sandor, P., Tsui, L.C. Linkage study of the dopamine D5 receptor gene and Gilles de la Tourette syndrome. Am. J. Med. Genet. 1997, 74: 58-61.

[53] Brett, P.M., Curtis, D., Robertson, M.M., Gurling, H.M. The genetic susceptibility to Gilles de la Tourette syndrome in a large 
multiple affected British kindred: linkage analysis excludes a role for the genes coding for dopamine D1, D2, D3, D4, D5 receptors, dopamine beta hydroxylase, tyrosinase, and tyrosine hydroxylase. Biol. Psychiatry 1995, 37: 533-40.

[54] Abelson, J.F., Kwan, K.Y., O'Roak, B.J., Baek, D.Y., Stillman, A.A., Morgan, T.M., Mathews, C.A., Pauls, D.L., Rasin, M.R., Gunel, M., Davis, N.R., Ercan-Sencicek, A.G., Guez, D.H., Spertus, J.A., Leckman, J.F., Dure, L.S.t., Kurlan, R., Singer, H.S., Gilbert, D.L., Farhi, A., Louvi, A., Lifton, R.P., Sestan, N., State, M.W. Sequence variants in SLITRK1 are associated with Tourette's syndrome. Science 2005, 310: 317-20.

[55] Shaywitz, S.E., Shaywitz, B.A., Fletcher, J.M., Escobar, M.D. Prevalence of reading disability in boys and girls. Results of the Connecticut Longitudinal Study. Jama 1990, 264: 998-1002.

[56] Caylak, E. A review of association and linkage studies for genetical analyses of learning disorders. Am. J. Med. Genet. B Neuropsychiatr. Genet. 2007, 144: 923-43.

[57] Taipale, M., Kaminen, N., Nopola-Hemmi, J., Haltia, T., Myllyluoma, B., Lyytinen, H., Muller, K., Kaaranen, M., Lindsberg, P.J., Hannula-Jouppi, K., Kere, J. A candidate gene for developmental dyslexia encodes a nuclear tetratricopeptide repeat domain protein dynamically regulated in brain. Proc. Natl. Acad. Sci. USA 2003, 100: $11553-8$

[58] Hannula-Jouppi, K., Kaminen-Ahola, N., Taipale, M., Eklund, R., Nopola-Hemmi, J., Kaariainen, H., Kere, J. The axon guidance receptor gene ROBO1 is a candidate gene for developmental dyslexia. PLoS Genet. 2005, 1: e50.

[59] Meng, H., Smith, S.D., Hager, K., Held, M., Liu, J., Olson, R.K., Pennington, B.F., DeFries, J.C., Gelernter, J., O'Reilly-Pol, T., Somlo, S., Skudlarski, P., Shaywitz, S.E., Shaywitz, B.A., Marchione, K., Wang, Y., Paramasivam, M., LoTurco, J.J., Page, G.P., Gruen, J.R. DCDC2 is associated with reading disability and modulates neuronal development in the brain. Proc. Natl. Acad. Sci. USA 2005, 102: 17053-8

[60] Kjeldsen, M.J., Kyvik, K.O., Friis, M.L., Christensen, K. Genetic and environmental factors in febrile seizures: a Danish populationbased twin study. Epilepsy Res. 2002, 51: 167-77.

[61] Johnson, E.W., Dubovsky, J., Rich, S.S., O'Donovan, C.A., Orr, H.T., Anderson, V.E., Gil-Nagel, A., Ahmann, P., Dokken, C.G., Schneider, D.T., Weber, J.L. Evidence for a novel gene for familial febrile convulsions, FEB2, linked to chromosome 19p in an extended family from the Midwest. Hum. Mol. Genet. 1998, 7: 63-7.

[62] Peiffer, A., Thompson, J., Charlier, C., Otterud, B., Varvil, T., Pappas, C., Barnitz, C., Gruenthal, K., Kuhn, R., Leppert, M. A locus for febrile seizures (FEB3) maps to chromosome 2q23-24. Ann. Neurol. 1999, 46: 671-8

[63] Nakayama, J., Hamano, K., Iwasaki, N., Nakahara, S., Horigome, Y., Saitoh, H., Aoki, T., Maki, T., Kikuchi, M., Migita, T., Ohto, T., Yokouchi, Y., Tanaka, R., Hasegawa, M., Matsui, A., Hamaguchi, H., Arinami, T. Significant evidence for linkage of febrile seizures to chromosome 5q14-q15. Hum. Mol. Genet. 2000, 9: 87-91.

[64] Nakayama, J., Yamamoto, N., Hamano, K., Iwasaki, N., Ohta, M., Nakahara, S., Matsui, A., Noguchi, E., Arinami, T. Linkage and association of febrile seizures to the IMPA2 gene on human chromosome 18. Neurology 2004, 63: 1803-7.

[65] Yinan, M., Yu, Q., Zhiyue, C., Jianjun, L., Lie, H., Liping, Z., Jianhui, Z., Fang, S., Dingfang, B., Qing, L., Xiru, W. Polymorphisms of casein kinase I gamma 2 gene associated with simple febrile seizures in Chinese Han population. Neurosci. Lett. 2004, 368: 2-6.

[66] Feucht, M., Fuchs, K., Pichlbauer, E., Hornik, K., Scharfetter, J., Goessler, R., Fureder, T., Cvetkovic, N., Sieghart, W., Kasper, S., Aschauer, H. Possible association between childhood absence epilepsy and the gene encoding GABRB3. Biol. Psychiatry 1999, 46: 997-1002.

[67] Steinlein, O., Sander, T., Stoodt, J., Kretz, R., Janz, D., Propping, P. Possible association of a silent polymorphism in the neuronal nicotinic acetylcholine receptor subunit alpha4 with common idiopathic generalized epilepsies. Am. J. Med. Genet. 1997, 74: 445-9.

[68] Kanemoto, K., Kawasaki, J., Miyamoto, T., Obayashi, H., Nishimura, M. Interleukin (IL)1beta, IL-1alpha, and IL-1 receptor antagonist gene polymorphisms in patients with temporal lobe epilepsy. Ann. Neurol. 2000, 47: 571-4.

[69] Tsai, F.J., Hsieh, Y.Y., Chang, C.C., Lin, C.C., Tsai, C.H. Polymorphisms for interleukin 1 beta exon 5 and interleukin 1 receptor antagonist in Taiwanese children with febrile convulsions. Arch. Pediatr. Adolesc. Med. 2002, 156: 545-8.

[70] Baulac, S., Huberfeld, G., Gourfinkel-An, I., Mitropoulou, G., Beranger, A., Prud'homme, J.F., Baulac, M., Brice, A., Bruzzone, R., LeGuern, E. First genetic evidence of GABA(A) receptor dysfunction in epilepsy: a mutation in the gamma2-subunit gene. Nat. Genet. 2001, 28: 46-8.

[71] Nakayama, J., Hamano, K., Noguchi, E., Horiuchi, Y., Iwasaki, N., Ohta, M., Nakahara, S., Naoi, T., Matsui, A., Arinami, T. Failure to find causal mutations in the GABA(A)-receptor gamma2 subunit (GABRG2) gene in Japanese febrile seizure patients. Neurosci. Lett. 2003, 343: 117-20.

[72] Tilgen, N., Pfeiffer, H., Cobilanschi, J., Rau, B., Horvath, S., Elger, C.E., Propping, P., Heils, A. Association analysis between the human interleukin 1 beta $(-511)$ gene polymorphism and susceptibility to febrile convulsions. Neurosci. Lett. 2002, 334: 68-70.

[73] Mulley, J., Heron, S., Scheffer, I., Berkovic, S. Febrile convulsions and genetic susceptibility: role of the neuronal nicotinic acetylcholine receptor alpha 4 subunit. Epilepsia 2004, 45: 561; author reply 561-2.

[74] Haspolat, S., Baysal, Y., Duman, O., Coskun, M., Tosun, O., Yegin, O. Interleukin-1alpha, interleukin-1beta, and interleukin1 Ra polymorphisms in febrile seizures. J. Child Neurol. 2005, 20: 565-8.

[75] Hempelmann, A., Cobilanschi, J., Heils, A., Muhle, H., Stephani, U., Weber, Y., Lerche, H., Sander, T. Lack of evidence of an allelic association of a functional GABRB3 exon 1a promoter polymorphism with idiopathic generalized epilepsy. Epilepsy Res. 2007, 74: 28-32.

[76] Chelly, J., Mandel, J.L. Monogenic causes of X-linked mental retardation. Nat. Rev. Genet. 2001, 2: 669-80.

[77] Batshaw, M.L. Mental retardation. Pediatr. Clin. North Am. 1993, 40: $507-21$

[78] Hagberg, B., Kyllerman, M. Epidemiology of mental retardation--a Swedish survey. Brain Dev. 1983, 5: 441-9.

[79] Gecz, J., Gedeon, A.K., Sutherland, G.R., Mulley, J.C. Identification of the gene FMR2, associated with FRAXE mental retardation. Nat. Genet. 1996, 13: 105-8.

[80] Billuart, P., Bienvenu, T., Ronce, N., des Portes, V., Vinet, M.C. Zemni, R., Roest Crollius, H., Carrie, A., Fauchereau, F., Cherry, M., Briault, S., Hamel, B., Fryns, J.P., Beldjord, C., Kahn, A., Moraine, C., Chelly, J. Oligophrenin-1 encodes a rhoGAP protein involved in X-linked mental retardation. Nature 1998, 392: 923-6.

[81] Allen, K.M., Gleeson, J.G., Bagrodia, S., Partington, M.W., MacMillan, J.C., Cerione, R.A., Mulley, J.C., Walsh, C.A. PAK3 mutation in nonsyndromic X-linked mental retardation. Nat. Genet. 1998, 20: 25-30.

[82] D'Adamo, P., Menegon, A., Lo Nigro, C., Grasso, M., Gulisano, M., Tamanini, F., Bienvenu, T., Gedeon, A.K., Oostra, B., Wu, S.K., Tandon, A., Valtorta, F., Balch, W.E., Chelly, J., Toniolo, D. Mutations in GDI1 are responsible for X-linked non-specific mental retardation. Nat. Genet. 1998, 19: 134-9.

[83] Kutsche, K., Yntema, H., Brandt, A., Jantke, I., Nothwang, H.G., Orth, U., Boavida, M.G., David, D., Chelly, J., Fryns, J.P., Moraine, C., Ropers, H.H., Hamel, B.C., van Bokhoven, H., Gal, A. Mutations in ARHGEF6, encoding a guanine nucleotide exchange factor for Rho GTPases, in patients with X-linked mental retardation. Nat. Genet. 2000, 26: 247-50.

[84] Merienne, K., Jacquot, S., Pannetier, S., Zeniou, M., Bankier, A. Gecz, J., Mandel, J.L., Mulley, J., Sassone-Corsi, P., Hanauer, A. A missense mutation in RPS6KA3 (RSK2) responsible for nonspecific mental retardation. Nat. Genet. 1999, 22: 13-4.

[85] Carrie, A., Jun, L., Bienvenu, T., Vinet, M.C., McDonell, N., Couvert, P., Zemni, R., Cardona, A., Van Buggenhout, G., Frints, S., Hamel, B., Moraine, C., Ropers, H.H., Strom, T., Howell, G.R., Whittaker, A., Ross, M.T., Kahn, A., Fryns, J.P., Beldjord, C., Marynen, P., Chelly, J. A new member of the IL-1 receptor family highly expressed in hippocampus and involved in X-linked mental retardation. Nat. Genet. 1999, 23: 25-31.

[86] Zemni, R., Bienvenu, T., Vinet, M.C., Sefiani, A., Carrie, A., Billuart, P., McDonell, N., Couvert, P., Francis, F., Chafey, P., Fauchereau, F., Friocourt, G., des Portes, V., Cardona, A., Frints, S., Meindl, A., Brandau, O., Ronce, N., Moraine, C., van Bokhoven, H., Ropers, H.H., Sudbrak, R., Kahn, A., Fryns, J.P., Beldjord, C., Chelly, J. A new gene involved in X-linked mental retardation 
identified by analysis of an X;2 balanced translocation. Nat. Genet. 2000, 24: 167-70.

[87] Couvert, P., Bienvenu, T., Aquaviva, C., Poirier, K., Moraine, C., Gendrot, C., Verloes, A., Andres, C., Le Fevre, A.C., Souville, I., Steffann, J., des Portes, V., Ropers, H.H., Yntema, H.G., Fryns, J.P., Briault, S., Chelly, J., Cherif, B. MECP2 is highly mutated in X-linked mental retardation. Hum. Mol. Genet. 2001, 10: 941-6.

[88] Meloni, I., Muscettola, M., Raynaud, M., Longo, I., Bruttini, M., Moizard, M.P., Gomot, M., Chelly, J., des Portes, V., Fryns, J.P., Ropers, H.H., Magi, B., Bellan, C., Volpi, N., Yntema, H.G., Lewis, S.E., Schaffer, J.E., Renieri, A. FACL4, encoding fatty acid-CoA ligase 4 , is mutated in nonspecific X-linked mental retardation. Nat. Genet. 2002, 30: 436-40.

[89] Stromme, P., Mangelsdorf, M.E., Shaw, M.A., Lower, K.M., Lewis, S.M., Bruyere, H., Lutcherath, V., Gedeon, A.K., Wallace, R.H., Scheffer, I.E., Turner, G., Partington, M., Frints, S.G., Fryns, J.P., Sutherland, G.R., Mulley, J.C., Gecz, J. Mutations in the human ortholog of Aristaless cause X-linked mental retardation and epilepsy. Nat. Genet. 2002, 30: 441-5.

[90] Hiroi, N., Agatsuma, S. Genetic susceptibility to substance dependence. Mol. Psychiatry 2005, 10: 336-44.

[91] Sullivan, P.F., Kendler, K.S. The genetic epidemiology of smoking. Nicotine Tob. Res. 1999, 1 Suppl 2: S51-7; discussion S69-70.

[92] Guindalini, C., Howard, M., Haddley, K., Laranjeira, R., Collier, D., Ammar, N., Craig, I., O'Gara, C., Bubb, V.J., Greenwood, T., Kelsoe, J., Asherson, P., Murray, R.M., Castelo, A., Quinn, J.P., Vallada, H., Breen, G. A dopamine transporter gene functional variant associated with cocaine abuse in a Brazilian sample. Proc. Natl. Acad. Sci. USA 2006, 103: 4552-7.

[93] Muramatsu, T., Higuchi, S. Dopamine transporter gene polymorphism and alcoholism. Biochem. Biophys. Res. Commun. 1995, 211: 28-32.

[94] Timberlake, D.S., Haberstick, B.C., Lessem, J.M., Smolen, A., Ehringer, M., Hewitt, J.K., Hopfer, C. An association between the DAT1 polymorphism and smoking behavior in young adults from the National Longitudinal Study of Adolescent Health. Health Psychol. 2006, 25: 190-7.

[95] Noble, E.P., Blum, K., Khalsa, M.E., Ritchie, T., Montgomery, A., Wood, R.C., Fitch, R.J., Ozkaragoz, T., Sheridan, P.J., Anglin, M.D., Parades, A., Treiman, L.J., Sparkes, R.S. Allelic association of the D2 dopamine receptor gene with cocaine dependence. Drug Alcohol Depend. 1993, 33: 271-85.

[96] Blum, K., Noble, E.P., Sheridan, P.J., Montgomery, A., Ritchie, T., Jagadeeswaran, P., Nogami, H., Briggs, A.H., Cohn, J.B. Allelic association of human dopamine D2 receptor gene in alcoholism. JAMA 1990, 263: 2055-60.

[97] Xu, K., Lichtermann, D., Lipsky, R.H., Franke, P., Liu, X., Hu, Y., Cao, L., Schwab, S.G., Wildenauer, D.B., Bau, C.H., Ferro, E., Astor, W., Finch, T., Terry, J., Taubman, J., Maier, W., Goldman, D. Association of specific haplotypes of D2 dopamine receptor gene with vulnerability to heroin dependence in 2 distinct populations. Arch. Gen. Psychiatry 2004, 61: 597-606.

[98] Duaux, E., Gorwood, P., Griffon, N., Bourdel, M.C., Sautel, F., Sokoloff, P., Schwartz, J.C., Ades, J., Loo, H., Poirier, M.F. Homozygosity at the dopamine D3 receptor gene is associated with opiate dependence. Mol. Psychiatry 1998, 3: 333-6.

[99] Comings, D.E., Gonzalez, N., Wu, S., Saucier, G., Johnson, P., Verde, R., MacMurray, J.P. Homozygosity at the dopamine DRD3 receptor gene in cocaine dependence. Mol. Psychiatry 1999, 4: 484-7.

[100] Tiihonen, J., Hallikainen, T., Lachman, H., Saito, T., Volavka, J., Kauhanen, J., Salonen, J.T., Ryynanen, O.P., Koulu, M., Karvonen, M.K., Pohjalainen, T., Syvalahti, E., Hietala, J. Association between the functional variant of the catechol-O-methyltransferase (COMT) gene and type 1 alcoholism. Mol. Psychiatry 1999, 4: 286-9.

[101] Horowitz, R., Kotler, M., Shufman, E., Aharoni, S., Kremer, I., Cohen, H., Ebstein, R.P. Confirmation of an excess of the high enzyme activity COMT val allele in heroin addicts in a family-based haplotype relative risk study. Am. J. Med. Genet. 2000, 96: 599603 .

[102] Munafo, M., Clark, T., Johnstone, E., Murphy, M., Walton, R. The genetic basis for smoking behavior: a systematic review and metaanalysis. Nicotine Tob. Res. 2004, 6: 583-97.

[103] Munafo, M.R., Matheson, I.J., Flint, J. Association of the DRD2 gene Taq1A polymorphism and alcoholism: a meta-analysis of case-control studies and evidence of publication bias. Mol. Psychiatry 2007, 12: 454-61.

[104] Green, R.F., Stoler, J.M. Alcohol dehydrogenase 1B genotype and fetal alcohol syndrome: a HuGE minireview. Am. J. Obstet. Gynecol. 2007, 197: 12-25.

[105] Rasheed, A., Hines, R.N., McCarver-May, D.G. Variation in induction of human placental CYP2E1: possible role in susceptibility to fetal alcohol syndrome? Toxicol. Appl. Pharmacol. 1997, 144: 396400.

[106] Boutelet-Bochan, H., Huang, Y., Juchau, M.R. Expression of CYP2E1 during embryogenesis and fetogenesis in human cephalic tissues: implications for the fetal alcohol syndrome. Biochem. Biophys. Res. Commun. 1997, 238: 443-7.

[107] Kessler, R.C., McGonagle, K.A., Zhao, S., Nelson, C.B., Hughes, M., Eshleman, S., Wittchen, H.U., Kendler, K.S. Lifetime and 12 month prevalence of DSM-III-R psychiatric disorders in the United States. Results from the National Comorbidity Survey. Arch. Gen. Psychiatry 1994, 51: 8-19.

[108] Hettema, J.M., Neale, M.C., Kendler, K.S. A review and metaanalysis of the genetic epidemiology of anxiety disorders. Am. J. Psychiatry 2001, 158: 1568-78.

[109] Hamilton, S.P., Fyer, A.J., Durner, M., Heiman, G.A., Baisre de Leon, A., Hodge, S.E., Knowles, J.A., Weissman, M.M. Further genetic evidence for a panic disorder syndrome mapping to chromosome 13q. Proc. Natl. Acad. Sci. USA 2003, 100: 2550-5.

[110] Thorgeirsson, T.E., Oskarsson, H., Desnica, N., Kostic, J.P., Stefansson, J.G., Kolbeinsson, H., Lindal, E., Gagunashvili, N., Frigge, M.L., Kong, A., Stefansson, K., Gulcher, J.R. Anxiety with panic disorder linked to chromosome $9 \mathrm{q}$ in Iceland. Am. J. Hum. Genet. 2003, 72: 1221-30.

[111] Hanna, G.L., Veenstra-Vanderweele, J., Cox, N.J., Van Etten, M., Fischer, D.J., Himle, J.A., Bivens, N.C., Wu, X., Roe, C.A., Hennessy, K.A., Dickel, D.E., Leventhal, B.L., Cook, E.H. Jr. Evidence for a susceptibility locus on chromosome $10 \mathrm{p} 15$ in early-onset obsessive-compulsive disorder. Biol. Psychiatry 2007, 62: 856-62.

[112] Hanna, G.L., Veenstra-VanderWeele, J., Cox, N.J., Boehnke, M., Himle, J.A., Curtis, G.C., Leventhal, B.L., Cook, E.H., Jr. Genomewide linkage analysis of families with obsessive-compulsive disorder ascertained through pediatric probands. Am. J. Med. Genet. 2002, 114: 541-52.

[113] Samuels, J., Shugart, Y.Y., Grados, M.A., Willour, V.L., Bienvenu, O.J., Greenberg, B.D., Knowles, J.A., McCracken, J.T., Rauch, S.L., Murphy, D.L., Wang, Y., Pinto, A., Fyer, A.J., Piacentini, J., Pauls, D.L., Cullen, B., Rasmussen, S.A., Hoehn-Saric, R., Valle, D., Liang, K.Y., Riddle, M.A., Nestadt, G. Significant linkage to compulsive hoarding on chromosome 14 in families with obsessive-compulsive disorder: results from the OCD Collaborative Genetics Study. Am. J. Psychiatry 2007, 164: 493-9.

[114] Shugart, Y.Y., Samuels, J., Willour, V.L., Grados, M.A., Greenberg, B.D., Knowles, J.A., McCracken, J.T., Rauch, S.L., Murphy, D.L., Wang, Y., Pinto, A., Fyer, A.J., Piacentini, J., Pauls, D.L., Cullen, B., Page, J., Rasmussen, S.A., Bienvenu, O.J., HoehnSaric, R., Valle, D., Liang, K.Y., Riddle, M.A., Nestadt, G. Genomewide linkage scan for obsessive-compulsive disorder: evidence for susceptibility loci on chromosomes 3q, 7p, 1q, 15q, and 6q. Mol. Psychiatry 2006, 11: 763-70.

[115] Gelernter, J., Page, G.P., Bonvicini, K., Woods, S.W., Pauls, D.L., Kruger, S. A chromosome 14 risk locus for simple phobia: results from a genomewide linkage scan. Mol. Psychiatry 2003, 8: 71-82.

[116] Gelernter, J., Page, G.P., Stein, M.B., Woods, S.W. Genome-wide linkage scan for loci predisposing to social phobia: evidence for a chromosome 16 risk locus. Am. J. Psychiatry 2004, 161: 59-66.

[117] Fullerton, J., Cubin, M., Tiwari, H., Wang, C., Bomhra, A., Davidson, S., Miller, S., Fairburn, C., Goodwin, G., Neale, M.C., Fiddy, S., Mott, R., Allison, D.B., Flint, J. Linkage analysis of extremely discordant and concordant sibling pairs identifies quantitative-trait loci that influence variation in the human personality trait neuroticism. Am. J. Hum. Genet. 2003, 72: 879-90.

[118] Cloninger, C.R., Van Eerdewegh, P., Goate, A., Edenberg, H.J., Blangero, J., Hesselbrock, V., Reich, T., Nurnberger, J., Jr., Schuckit, M., Porjesz, B., Crowe, R., Rice, J.P., Foroud, T., Przybeck, T.R., Almasy, L., Bucholz, K., Wu, W., Shears, S., Carr, K., Crose, C., Willig, C., Zhao, J., Tischfield, J.A., Li, T.K., Conneally, P.M., Begleiter, H. Anxiety proneness linked to epistatic loci in genome scan of human personality traits. Am. J. Med. Genet. 1998, 81: 313-7. 
[119] Middeldorp, C.M., Hottenga, J.J., Slagboom, P.E., Sullivan, P.F., de Geus, E.J., Posthuma, D., Willemsen, G., Boomsma, D.I. Linkage on chromosome 14 in a genome-wide linkage study of a broad anxiety phenotype. Mol. Psychiatry 2008, 13: 84-9.

[120] Kaabi, B., Gelernter, J., Woods, S.W., Goddard, A., Page, G.P., Elston, R.C. Genome scan for loci predisposing to anxiety disorders using a novel multivariate approach: strong evidence for a chromosome 4 risk locus. Am. J. Hum. Genet. 2006, 78: 543-53.

[121] Rothe, C., Gutknecht, L., Freitag, C., Tauber, R., Mossner, R., Franke, P., Fritze, J., Wagner, G., Peikert, G., Wenda, B., Sand, P., Jacob, C., Rietschel, M., Nothen, M.M., Garritsen, H., Fimmers, R., Deckert, J., Lesch, K.P. Association of a functional 1019C>G 5-HT1A receptor gene polymorphism with panic disorder with agoraphobia. Int. J. Neuropsychopharmacol. 2004, 7: 189-92.

[122] Inada, Y., Yoneda, H., Koh, J., Sakai, J., Himei, A., Kinoshita, Y., Akabame, K., Hiraoka, Y., Sakai, T. Positive association between panic disorder and polymorphism of the serotonin $2 \mathrm{~A}$ receptor gene. Psychiatry Res. 2003, 118: 25-31.

[123] Domschke, K., Freitag, C.M., Kuhlenbaumer, G., Schirmacher, A., Sand, P., Nyhuis, P., Jacob, C., Fritze, J., Franke, P., Rietschel, M., Garritsen, H.S., Fimmers, R., Nothen, M.M., Lesch, K.P., Stogbauer, F., Deckert, J. Association of the functional V158M catechol-O-methyl-transferase polymorphism with panic disorder in women. Int. J. Neuropsychopharmacol. 2004, 7: 183-8.

[124] Miyasaka, K., Yoshida, Y., Matsushita, S., Higuchi, S., Shirakawa, O., Shimokata, H., Funakoshi, A. Association of cholecystokinin-A receptor gene polymorphisms and panic disorder in Japanese. Am. J. Med. Genet. B Neuropsychiatr. Genet. 2004, 127: 78-80.

[125] Deckert, J., Nothen, M.M., Franke, P., Delmo, C., Fritze, J., Knapp, M., Maier, W., Beckmann, H., Propping, P. Systematic mutation screening and association study of the A1 and A2a adenosine receptor genes in panic disorder suggest a contribution of the A2a gene to the development of disease. Mol. Psychiatry 1998, 3: 81-5.

[126] Deckert, J., Catalano, M., Syagailo, Y.V., Bosi, M., Okladnova, O., Di Bella, D., Nothen, M.M., Maffei, P., Franke, P., Fritze, J., Maier, W., Propping, P., Beckmann, H., Bellodi, L., Lesch, K.P. Excess of high activity monoamine oxidase A gene promoter alleles in female patients with panic disorder. Hum. Mol. Genet. 1999, 8: 621-4.

[127] Domschke, K., Kuhlenbaumer, G., Schirmacher, A., Lorenzi, C., Armengol, L., DiBella, D., Gratacos, M., Garritsen, H.S., Nothen, M.M., Franke, P., Sand, P., Fritze, J., Perez, G., Maier, W., Sibrowski, W., Estivill, X., Bellodi, L., Ringelstein, E.B., Arolt, V., Martin-Santos, R., Catalano, M., Stogbauer, F., Deckert, J. Human nuclear transcription factor gene CREM: genomic organization, mutation screening, and association analysis in panic disorder. Am. J. Med. Genet. B Neuropsychiatr. Genet. 2003, 117: 70-8.

[128] Nakamura, K., Yamada, K., Iwayama, Y., Toyota, T., Furukawa, A., Takimoto, T., Terayama, H., Iwahashi, K., Takei, N., Minabe, Y., Sekine, Y., Suzuki, K., Iwata, Y., Pillai, A., Nakamoto, Y., Ikeda, K., Yoshii, M., Fukunishi, I., Yoshikawa, T., Mori, N. Evidence that variation in the peripheral benzodiazepine receptor (PBR) gene influences susceptibility to panic disorder. Am. J. Med. Genet. B Neuropsychiatr. Genet. 2006, 141: 222-6.

[129] Hettema, J.M., An, S.S., Neale, M.C., Bukszar, J., van den Oord, E.J., Kendler, K.S., Chen, X. Association between glutamic acid decarboxylase genes and anxiety disorders, major depression, and neuroticism. Mol. Psychiatry 2006, 11: 752-62.

[130] Thoeringer, C.K., Binder, E.B., Salyakina, D., Erhardt, A., Ising, M., Unschuld, P.G., Kern, N., Lucae, S., Brueckl, T.M., Mueller, M.B., Fuchs, B., Puetz, B., Lieb, R., Uhr, M., Holsboer, F., Mueller-Myhsok, B., Keck, M.E. Association of a Met88Val diazepam binding inhibitor (DBI) gene polymorphism and anxiety disorders with panic attacks. J. Psychiatr. Res. 2007, 41: 579-84.

[131] Erhardt, A., Lucae, S., Unschuld, P.G., Ising, M., Kern, N., Salyakina, D., Lieb, R., Uhr, M., Binder, E.B., Keck, M.E., MullerMyhsok, B., Holsboer, F. Association of polymorphisms in P2RX7 and CaMKKb with anxiety disorders. J. Affect. Disord. 2007, 101: 159-68.

[132] Olsson, M., Annerbrink, K., Westberg, L., Melke, J., Baghaei, F., Rosmond, R., Holm, G., Andersch, S., Allgulander, C., Eriksson, E. Angiotensin-related genes in patients with panic disorder. Am. $J$. Med. Genet. B Neuropsychiatr. Genet. 2004, 127: 81-4.

[133] Maron, E., Nikopensius, T., Koks, S., Altmae, S., Heinaste, E., Vabrit, K., Tammekivi, V., Hallast, P., Koido, K., Kurg, A., Metspalu, A., Vasar, E., Vasar, V., Shlik, J. Association study of 90 candidate gene polymorphisms in panic disorder. Psychiatr. Genet. 2005, 15: 17-24.

[134] Camarena, B., Aguilar, A., Loyzaga, C., Nicolini, H. A familybased association study of the 5-HT-1Dbeta receptor gene in obsessive-compulsive disorder. Int. J. Neuropsychopharmacol. 2004, 7: 49-53.

[135] Lochner, C., Hemmings, S.M., Kinnear, C.J., Moolman-Smook, J.C., Corfield, V.A., Knowles, J.A., Niehaus, D.J., Stein, D.J. Gender in obsessive-compulsive disorder: clinical and genetic findings. Eur. Neuropsychopharmacol. 2004, 14: 105-13.

[136] Meira-Lima, I., Shavitt, R.G., Miguita, K., Ikenaga, E., Miguel, E.C., Vallada, H. Association analysis of the catechol-omethyltransferase (COMT), serotonin transporter (5-HTT) and serotonin $2 \mathrm{~A}$ receptor $(5 \mathrm{HT} 2 \mathrm{~A}$ ) gene polymorphisms with obsessivecompulsive disorder. Genes Brain Behav. 2004, 3: 75-9.

[137] Lesch, K.P., Bengel, D., Heils, A., Sabol, S.Z., Greenberg, B.D., Petri, S., Benjamin, J., Muller, C.R., Hamer, D.H., Murphy, D.L. Association of anxiety-related traits with a polymorphism in the serotonin transporter gene regulatory region. Science 1996, 274: 1527-31.

[138] Schinka, J.A., Busch, R.M., Robichaux-Keene, N. A meta-analysis of the association between the serotonin transporter gene polymorphism (5-HTTLPR) and trait anxiety. Mol. Psychiatry 2004, 9: 197-202.

[139] Sen, S., Burmeister, M., Ghosh, D. Meta-analysis of the association between a serotonin transporter promoter polymorphism (5HTTLPR) and anxiety-related personality traits. Am. J. Med. Genet. B Neuropsychiatr. Genet. 2004, 127: 85-9.

[140] Tadic, A., Rujescu, D., Szegedi, A., Giegling, I., Singer, P., Moller, H.J., Dahmen, N. Association of a MAOA gene variant with generalized anxiety disorder, but not with panic disorder or major depression. Am. J. Med. Genet. B Neuropsychiatr. Genet. 2003, 117: $1-6$.

[141] Eley, T.C., Tahir, E., Angleitner, A., Harriss, K., McClay, J., Plomin, R., Riemann, R., Spinath, F., Craig, I. Association analysis of MAOA and COMT with neuroticism assessed by peers. Am. $J$. Med. Genet. B Neuropsychiatr. Genet. 2003, 120: 90-6.

[142] McGrath, M., Kawachi, I., Ascherio, A., Colditz, G.A., Hunter, D.J., De Vivo, I. Association between catechol-Omethyltransferase and phobic anxiety. Am. J. Psychiatry 2004, 161: 1703-5.

[143] Hunnerkopf, R., Strobel, A., Gutknecht, L., Brocke, B., Lesch, K.P. Interaction between BDNF Val66Met and dopamine transporter gene variation influences anxiety-related traits. Neuropsychopharmacology 2007, 32: 2552-60.

[144] Lang, U.E., Hellweg, R., Kalus, P., Bajbouj, M., Lenzen, K.P., Sander, T., Kunz, D., Gallinat, J. Association of a functional BDNF polymorphism and anxiety-related personality traits. Psychopharmacology (Berl) 2005, 180: 95-9.

[145] Nemeroff, C.B., Bremner, J.D., Foa, E.B., Mayberg, H.S., North, C.S., Stein, M.B. Posttraumatic stress disorder: a state-of-thescience review. J. Psychiatr. Res. 2006, 40: 1-21.

[146] Breslau, N., Kessler, R.C., Chilcoat, H.D., Schultz, L.R., Davis, G.C., Andreski, P. Trauma and posttraumatic stress disorder in the community: the 1996 Detroit Area Survey of Trauma. Arch. Gen. Psychiatry 1998, 55: 626-32.

[147] Kessler, R.C., Sonnega, A., Bromet, E., Hughes, M., Nelson, C.B. Posttraumatic stress disorder in the National Comorbidity Survey. Arch. Gen. Psychiatry 1995, 52: 1048-60.

[148] True, W.R., Rice, J., Eisen, S.A., Heath, A.C., Goldberg, J., Lyons, M.J., Nowak, J. A twin study of genetic and environmental contributions to liability for posttraumatic stress symptoms. Arch. Gen. Psychiatry 1993, 50: 257-64.

[149] Zhang, H., Ozbay, F., Lappalainen, J., Kranzler, H.R., van Dyck, C.H., Charney, D.S., Price, L.H., Southwick, S., Yang, B.Z., Rasmussen, A., Gelernter, J. Brain derived neurotrophic factor (BDNF) gene variants and Alzheimer's disease, affective disorders, posttraumatic stress disorder, schizophrenia, and substance dependence. Am. J. Med. Genet. B Neuropsychiatr. Genet. 2006, 141: 387-93.

[150] Lappalainen, J., Kranzler, H.R., Malison, R., Price, L.H., Van Dyck, C., Rosenheck, R.A., Cramer, J., Southwick, S., Charney, D., Krystal, J., Gelernter, J. A functional neuropeptide Y Leu7Pro polymorphism associated with alcohol dependence in a large population sample from the United States. Arch. Gen. Psychiatry 2002 59: 825-31. 
[151] Bachmann, A.W., Sedgley, T.L., Jackson, R.V., Gibson, J.N., Young, R.M., Torpy, D.J. Glucocorticoid receptor polymorphisms and post-traumatic stress disorder. Psychoneuroendocrinology 2005, 30: 297-306.

[152] Lee, H.J., Lee, M.S., Kang, R.H., Kim, H., Kim, S.D., Kee, B.S., Kim, Y.H., Kim, Y.K., Kim, J.B., Yeon, B.K., Oh, K.S., Oh, B.H., Yoon, J.S., Lee, C., Jung, H.Y., Chee, I.S., Paik, I.H. Influence of the serotonin transporter promoter gene polymorphism on susceptibility to posttraumatic stress disorder. Depress. Anxiety 2005, 21: 135-9.

[153] Comings, D.E., Muhleman, D., Gysin, R. Dopamine D2 receptor (DRD2) gene and susceptibility to posttraumatic stress disorder: a study and replication. Biol. Psychiatry 1996, 40: 368-72.

[154] Bulik, C.M., Sullivan, P.F., Kendler, K.S. Heritability of bingeeating and broadly defined bulimia nervosa. Biol. Psychiatry 1998, 44: $1210-8$.

[155] Klump, K.L., Miller, K.B., Keel, P.K., McGue, M., Iacono, W.G. Genetic and environmental influences on anorexia nervosa syndromes in a population-based twin sample. Psychol. Med. 2001, 31: 737-40.

[156] Kortegaard, L.S., Hoerder, K., Joergensen, J., Gillberg, C., Kyvik, K.O. A preliminary population-based twin study of self-reported eating disorder. Psychol. Med. 2001, 31: 361-5.

[157] Kendler, K.S., MacLean, C., Neale, M., Kessler, R., Heath, A., Eaves, L. The genetic epidemiology of bulimia nervosa. Am. J. Psychiatry 1991, 148: 1627-37.

[158] Collier, D.A., Arranz, M.J., Li, T., Mupita, D., Brown, N., Treasure, J. Association between 5-HT2A gene promoter polymorphism and anorexia nervosa. Lancet 1997, 350: 412.

[159] Westberg, L., Bah, J., Rastam, M., Gillberg, C., Wentz, E., Melke, J., Hellstrand, M., Eriksson, E. Association between a polymorphism of the 5-HT2C receptor and weight loss in teenage girls. Neuropsychopharmacology 2002, 26: 789-93.

[160] Di Bella, D.D., Catalano, M., Cavallini, M.C., Riboldi, C., Bellodi, L. Serotonin transporter linked polymorphic region in anorexia nervosa and bulimia nervosa. Mol. Psychiatry 2000, 5: 233-4.

[161] Campbell, D.A., Sundaramurthy, D., Markham, A.F., Pieri, L.F. Lack of association between 5-HT2A gene promoter polymorphism and susceptibility to anorexia nervosa. Lancet 1998, 351: 499.

[162] Burnet, P.W., Smith, K.A., Cowen, P.J., Fairburn, C.G., Harrison, P.J. Allelic variation of the 5-HT2C receptor (HTR2C) in bulimia nervosa and binge eating disorder. Psychiatr. Genet. 1999, 9: 1014.

[163] Koizumi, H., Hashimoto, K., Itoh, K., Nakazato, M., Shimizu, E., Ohgake, S., Koike, K., Okamura, N., Matsushita, S., Suzuki, K., Murayama, M., Higuchi, S., Iyo, M. Association between the brainderived neurotrophic factor 196G/A polymorphism and eating disorders. Am. J. Med. Genet. B Neuropsychiatr. Genet. 2004, 127: 125-7.

[164] Ribases, M., Gratacos, M., Fernandez-Aranda, F., Bellodi, L., Boni, C., Anderluh, M., Cavallini, M.C., Cellini, E., Di Bella, D., Erzegovesi, S., Foulon, C., Gabrovsek, M., Gorwood, P., Hebebrand, J., Hinney, A., Holliday, J., Hu, X., Karwautz, A., Kipman, A., Komel, R., Nacmias, B., Remschmidt, H., Ricca, V., Sorbi, S., Wagner, G., Treasure, J., Collier, D.A., Estivill, X. Association of BDNF with anorexia, bulimia and age of onset of weight loss in six European populations. Hum. Mol. Genet. 2004, 13: 1205-12.

[165] Miyasaka, K., Hosoya, H., Sekime, A., Ohta, M., Amono, H., Matsushita, S., Suzuki, K., Higuchi, S., Funakoshi, A. Association of ghrelin receptor gene polymorphism with bulimia nervosa in a Japanese population. J. Neural Transm. 2006, 113: 1279-85.

[166] Frieling, H., Romer, K.D., Wilhelm, J., Hillemacher, T., Kornhuber, J., de Zwaan, M., Jacoby, G.E., Bleich, S. Association of catecholamine-O-methyltransferase and 5-HTTLPR genotype with eating disorder-related behavior and attitudes in females with eating disorders. Psychiatr. Genet. 2006, 16: 205-8.

[167] Mikolajczyk, E., Smiarowska, M., Grzywacz, A., Samochowiec, J. Association of eating disorders with catechol-o-methyltransferase gene functional polymorphism. Neuropsychobiology 2006, 54: 826.

[168] Frey, L., Hauser, W.A. Epidemiology of neural tube defects. Epilepsia 2003, 44 Suppl 3: 4-13.

[169] Padmanabhan, R. Etiology, pathogenesis and prevention of neural tube defects. Congenit. Anom. (Kyoto) 2006, 46: 55-67.

[170] Whitehead, A.S., Gallagher, P., Mills, J.L., Kirke, P.N., Burke, H., Molloy, A.M., Weir, D.G., Shields, D.C., Scott, J.M. A genetic de- fect in 5,10 methylenetetrahydrofolate reductase in neural tube defects. Qjm 1995, 88: 763-6.

[171] van der Linden, I.J., den Heijer, M., Afman, L.A., Gellekink, H., Vermeulen, S.H., Kluijtmans, L.A., Blom, H.J. The methionine synthase reductase $66 \mathrm{~A}>\mathrm{G}$ polymorphism is a maternal risk factor for spina bifida. J. Mol. Med. 2006, 84: 1047-54.

[172] Zhu, H., Wicker, N.J., Volcik, K., Zhang, J., Shaw, G.M., Lammer, E.J., Suarez, L., Canfield, M., Finnell, R.H. Promoter haplotype combinations for the human PDGFRA gene are associated with risk of neural tube defects. Mol. Genet. Metab. 2004, 81: 127-32.

[173] Brown, K.S., Cook, M., Hoess, K., Whitehead, A.S., Mitchell, L.E. Evidence that the risk of spina bifida is influenced by genetic variation at the NOS3 locus. Birth Defects Res. A Clin. Mol. Teratol. 2004, 70: 101-6.

[174] Zhu, H., Yang, W., Lu, W., Zhang, J., Shaw, G.M., Lammer, E.J., Finnell, R.H. A known functional polymorphism (Ile120Val) of the human PCMT1 gene and risk of spina bifida. Mol. Genet. Metab. 2006, 87: 66-70.

[175] Zhu, H., Enaw, J.O., Ma, C., Shaw, G.M., Lammer, E.J., Finnell, R.H. Association between CFL1 gene polymorphisms and spina bifida risk in a California population. BMC Med. Genet. 2007, 8: 12.

[176] Fernell, E., Hagberg, B., Hagberg, G., von Wendt, L. Epidemiology of infantile hydrocephalus in Sweden. I. Birth prevalence and general data. Acta Paediatr. Scand. 1986, 75: 975-81.

[177] Halliday, J., Chow, C.W., Wallace, D., Danks, D.M. X linked hydrocephalus: a survey of a 20 year period in Victoria, Australia. J. Med. Genet. 1986, 23: 23-31.

[178] Willems, P.J. Heterogeneity in familial hydrocephalus. Am. J. Med. Genet. 1988, 31: 471-3.

[179] Stoll, C., Alembik, Y., Dott, B., Roth, M.P. An epidemiologic study of environmental and genetic factors in congenital hydrocephalus. Eur. J. Epidemiol. 1992, 8: 797-803.

[180] Haverkamp, F., Wolfle, J., Aretz, M., Kramer, A., Hohmann, B., Fahnenstich, H., Zerres, K. Congenital hydrocephalus internus and aqueduct stenosis: aetiology and implications for genetic counselling. Eur. J. Pediatr. 1999, 158: 474-8.

[181] Zhang, J., Williams, M.A., Rigamonti, D. Genetics of human hydrocephalus. J. Neurol. 2006, 253: 1255-66.

[182] Schroeder, S.R. Mental retardation and developmental disabilities influenced by environmental neurotoxic insults. Environ. Health Perspect. 2000, 108 Suppl 3: 395-9.

[183] Fatemi, S.H., Earle, J., Kanodia, R., Kist, D., Emamian, E.S., Patterson, P.H., Shi, L., Sidwell, R. Prenatal viral infection leads to pyramidal cell atrophy and macrocephaly in adulthood: implications for genesis of autism and schizophrenia. Cell. Mol. Neurobiol. 2002, 22: 25-33.

[184] Boog, G. Obstetrical complications and subsequent schizophrenia in adolescent and young adult offsprings: is there a relationship? Eur. J. Obstet. Gynecol. Reprod. Biol. 2004, 114: 130-6.

[185] Curatolo, P., Arpino, C., Stazi, M.A., Medda, E. Risk factors for the co-occurrence of partial epilepsy, cerebral palsy and mental retardation. Dev. Med. Child Neurol. 1995, 37: 776-82.

[186] Torrey, E.F., Rawlings, R.R., Ennis, J.M., Merrill, D.D., Flores, D.S. Birth seasonality in bipolar disorder, schizophrenia, schizoaffective disorder and stillbirths. Schizophr. Res. 1996, 21: 141-9.

[187] Torrey, E.F., Miller, J., Rawlings, R., Yolken, R.H. Seasonality of births in schizophrenia and bipolar disorder: a review of the literature. Schizophr. Res. 1997, 28: 1-38.

[188] Mortensen, P.B., Pedersen, C.B., Westergaard, T., Wohlfahrt, J. Ewald, H., Mors, O., Andersen, P.K., Melbye, M. Effects of family history and place and season of birth on the risk of schizophrenia. N. Engl. J. Med. 1999, 340: 603-8.

[189] Yearwood, E.L., Crawford, S., Kelly, M., Moreno, N. Immigrant youth at risk for disorders of mood: recognizing complex dynamics. Arch. Psychiatr. Nurs. 2007, 21: 162-71.

[190] Cantor-Graae, E., Pedersen, C.B. Risk for schizophrenia in intercountry adoptees: a Danish population-based cohort study. J. Child Psychol. Psychiatry 2007, 48: 1053-60.

[191] Caspi, A., Moffitt, T.E., Cannon, M., McClay, J., Murray, R., Harrington, H., Taylor, A., Arseneault, L., Williams, B., Braithwaite, A., Poulton, R., Craig, I.W. Moderation of the effect of adolescentonset cannabis use on adult psychosis by a functional polymorphism in the catechol-O-methyltransferase gene: longitudinal evidence of a gene X environment interaction. Biol. Psychiatry $\mathbf{2 0 0 5}$ 57: 1117-27. 
[192] Wolffe, A.P., Matzke, M.A. Epigenetics: regulation through repression. Science 1999, 286: 481-6.

[193] Reik, W., Romer, I., Barton, S.C., Surani, M.A., Howlett, S.K., Klose, J. Adult phenotype in the mouse can be affected by epigenetic events in the early embryo. Development 1993, 119: 933-42.

[194] Rideout, W.M., 3rd, Eggan, K., Jaenisch, R. Nuclear cloning and epigenetic reprogramming of the genome. Science 2001, 293: 1093-8.

[195] Amir, R.E., Van den Veyver, I.B., Wan, M., Tran, C.Q., Francke, U., Zoghbi, H.Y. Rett syndrome is caused by mutations in X-linked MECP2, encoding methyl-CpG-binding protein 2. Nat. Genet. 1999, 23: 185-8.

[196] Xu, G.L., Bestor, T.H., Bourc'his, D., Hsieh, C.L., Tommerup, N., Bugge, M., Hulten, M., Qu, X., Russo, J.J., Viegas-Pequignot, E. Chromosome instability and immunodeficiency syndrome caused by mutations in a DNA methyltransferase gene. Nature 1999, 402: 187-91.

[197] Gibbons, R.J., McDowell, T.L., Raman, S., O'Rourke, D.M., Garrick, D., Ayyub, H., Higgs, D.R. Mutations in ATRX, encoding a SWI/SNF-like protein, cause diverse changes in the pattern of DNA methylation. Nat. Genet. 2000, 24: 368-71.

[198] Jin, P., Warren, S.T. Understanding the molecular basis of fragile $X$ syndrome. Hum. Mol. Genet. 2000, 9: 901-8.

[199] Pitkin, R.M. Folate and neural tube defects. Am. J. Clin. Nutr. 2007, 85: 285S-288S.

[200] Herran, A., Garcia-Unzueta, M.T., Amado, J.A., Lopez-Cordovilla, J.J., Diez-Manrique, J.F., Vazquez-Barquero, J.L. Folate levels in psychiatric outpatients. Psychiatry Clin. Neurosci. 1999, 53: 531-3.

[201] Tremolizzo, L., Carboni, G., Ruzicka, W.B., Mitchell, C.P., Sugaya, I., Tueting, P., Sharma, R., Grayson, D.R., Costa, E., Guidotti, A. An epigenetic mouse model for molecular and behavioral neuropathologies related to schizophrenia vulnerability. Proc. Natl. Acad. Sci. USA 2002, 99: 17095-100.

[202] Weaver, I.C., Cervoni, N., Champagne, F.A., D'Alessio, A.C., Sharma, S., Seckl, J.R., Dymov, S., Szyf, M., Meaney, M.J. Epigenetic programming by maternal behavior. Nat. Neurosci. 2004, 7: 847-54.

[203] Gottesman, II, Gould, T.D. The endophenotype concept in psychiatry: etymology and strategic intentions. Am. J. Psychiatry 2003, 160: 636-45.
[204] Flint, J., Munafo, M.R. The endophenotype concept in psychiatric genetics. Psychol. Med. 2007, 37: 163-80.

[205] Risch, N. Linkage strategies for genetically complex traits. I. Multilocus models. Am. J. Hum. Genet. 1990, 46: 222-8.

[206] Peng, B., Kimmel, M. Simulations provide support for the common disease-common variant hypothesis. Genetics 2007, 175: 763-76.

[207] Reich, D.E., Lander, E.S. On the allelic spectrum of human disease. Trends Genet. 2001, 17: 502-10.

[208] Pritchard, J.K. Are rare variants responsible for susceptibility to complex diseases? Am. J. Hum. Genet. 2001, 69: 124-37.

[209] Slager, S.L., Huang, J., Vieland, V.J. Effect of allelic heterogeneity on the power of the transmission disequilibrium test. Genet. Epidemiol. 2000, 18: 143-56.

[210] Wollstein, A., Herrmann, A., Wittig, M., Nothnagel, M., Franke, A., Nurnberg, P., Schreiber, S., Krawczak, M., Hampe, J. Efficacy assessment of SNP sets for genome-wide disease association studies. Nucleic Acids Res. 2007, 35: e113.

[211] Cargill, M., Altshuler, D., Ireland, J., Sklar, P., Ardlie, K., Patil, N., Shaw, N., Lane, C.R., Lim, E.P., Kalyanaraman, N., Nemesh, J., Ziaugra, L., Friedland, L., Rolfe, A., Warrington, J., Lipshutz, R., Daley, G.Q., Lander, E.S. Characterization of single-nucleotide polymorphisms in coding regions of human genes. Nat. Genet. 1999 , 22: 231-8.

[212] Jorde, L.B., Fineman, R.M., Martin, R.A. Epidemiology and genetics of neural tube defects: an application of the Utah Genealogical Data Base. Am. J. Phys. Anthropol. 1983, 62: 23-31.

[213] Hawke, J.L., Wadsworth, S.J., DeFries, J.C. Genetic influences on reading difficulties in boys and girls: the Colorado twin study. Dyslexia 2006, 12: 21-9.

[214] Fyer, A.J., Hamilton, S.P., Durner, M., Haghighi, F., Heiman, G.A., Costa, R., Evgrafov, O., Adams, P., de Leon, A.B., Taveras, N., Klein, D.F., Hodge, S.E., Weissman, M.M., Knowles, J.A. A third-pass genome scan in panic disorder: evidence for multiple susceptibility loci. Biol. Psychiatry 2006, 60: 388-401.

[215] Clifford, C.A., Murray, R.M., Fulker, D.W. Genetic and environmental influences on obsessional traits and symptoms. Psychol. Med. 1984, 14: 791-800.

[216] Jonnal, A.H., Gardner, C.O., Prescott, C.A., Kendler, K.S. Obsessive and compulsive symptoms in a general population sample of female twins. Am. J. Med. Genet. 2000, 96: 791-6. 